\title{
Emerging drugs of abuse: current perspectives on substituted cathinones
}

This article was published in the following Dove Press journal:

Substance Abuse and Rehabilitation

26 May 2014

Number of times this article has been viewed

\section{Magalie Paillet-Loilier' \\ Alexandre Cesbron' \\ Reynald Le Boisselier ${ }^{2}$ \\ Joanna Bourgine' \\ Danièle Debruyne ${ }^{1,2}$}

'Toxicology and Pharmacology

Laboratory, ${ }^{2}$ Centre

d'Evaluation et d'Information

sur la Pharmacodépendance

- Addictovigilance (CEIP-A),

Department of Pharmacology,

University Hospital Centre, Caen, France
Correspondance: Danièle Debruyne Centre d'Evaluation et d'Information sur la Pharmacodépendance Addictovigilance (CEIP-A), Department of Pharmacology, University Hospital Centre Côte de Nacre, I 4033 Caen cedex 9 , France

Tel +3323I0646 7I

$\mathrm{Fax}+33231064673$

Email debruyne-d@chu-caen.fr
Abstract: Substituted cathinones are synthetic analogs of cathinone that can be considered as derivatives of phenethylamines with a beta-keto group on the side chain. They appeared in the recreational drug market in the mid-2000s and now represent a large class of new popular drugs of abuse. Initially considered as legal highs, their legal status is variable by country and is rapidly changing, with government institutions encouraging their control. Some cathinones (such as diethylpropion or pyrovalerone) have been used in a medical setting and bupropion is actually indicated for smoking cessation. Substituted cathinones are widely available from internet websites, retail shops, and street dealers. They can be sold under chemical, evocative or generic names, making their identification difficult. Fortunately, analytical methods have been developed in recent years to solve this problem. Available as powders, substituted cathinones are self-administered by snorting, oral injestion, or intravenous injection. They act as central nervous system stimulants by causing the release of catecholamines (dopamine, noradrenaline, and serotonin) and blocking their reuptake in the central and peripheral nervous system. They may also decrease dopamine and serotonin transporter function as nonselective substrates or potent blockers and may inhibit monoamine oxidase effects. Nevertheless, considerable differences have been found in the potencies of the different substituted cathinones in vitro. Desired effects reported by users include increased energy, empathy, and improved libido. Cardiovascular (tachycardia, hypertension) and psychiatric/neurological signs/symptoms (agitation, seizures, paranoia, and hallucinations) are the most common adverse effects reported. Severe toxicity signs compatible with excessive serotonin activity, such as hyperthermia, metabolic acidosis, and prolonged rhabdomyolysis, have also been observed. Reinforcing potential observed in animals predicts a high potential for addiction and abuse in users. In case of overdose, no specific antidote exists and no curative treatment has been approved by health authorities. Therefore, management of acute toxic effects is mainly extrapolated from experience with cocaine/amphetamines.

Keywords: substituted cathinones, chemistry, analysis, pharmacology, toxicology, dependence, medical care

\section{Introduction}

Many recreational drugs have been synthesized chemically in recent decades as legal alternatives to scheduled cocaine and amphetamine/methamphetamine stimulants. Among them, synthetic derivatives of cathinone, also called substituted cathinones, have become increasingly popular among recreational drug users. The growing problem of the abuse of these psychoactive drugs, especially affecting youths, has prompted concerns from both health care providers and legal authorities. Moreover, in response to market trends and legislative controls, synthesis of new cathinone derivatives by introducing chemical modifications has dramatically increased the diversity of these substances. At 
the same time, since the appearance of substituted cathinones, ever-increasing data on the identification or analysis methods, pharmacokinetics or pharmacodynamics, animal or human toxicity, and addictive potential are becoming available. The aim of the current contribution is to present updated information on substituted cathinones, useful for poisons centers, clinical toxicologists, and emergency physicians.

\section{Chemical structure and designation}

Substituted cathinones are a large family of synthetic beta-keto phenethylamine (2-amino-1-phenyl-1-propanone) derivatives chemically related to the parent compound cathinone, a monoamine alkaloid naturally present in the khat plant, differing only in the functionality present at the beta-carbon; ie, ketone oxygen. As with amphetamines, both systematic (International Union of Pure and Applied Chemistry) and non-standard nomenclature is common in cathinone chemistry. The use of acronyms is also widespread. As a consequence of the betaketo substituent, it is also common practice for widely accepted amphetamine acronyms to be augmented with the prefix "bk". The most common cathinones and their related trade names are listed in Table 1. The general structure of a cathinone derivative (Figure 1) shows substitution patterns at four locations of the cathinone molecule; eg, on the carbon atom linked to the carbon in alpha position $\left(R_{1}\right)$, on the nitrogen atom $\left(R_{2}\right.$ and $\mathrm{R}_{3}$ ), and on the phenyl group $\left(\mathrm{R}_{4}\right)$. Substituents in $\mathrm{R}_{1}, \mathrm{R}_{2}, \mathrm{R}_{3}$, and $\mathrm{R}_{4}$ may vary, and include: alkyl, alkoxy, alkylenedioxy, haloalkyl, halide, and phenyl. However, differences between substituted cathinones may be limited to the simple addition of a methyl group (Table 2). For some substituted cathinones, nitrogen may be incorporated in a cyclic pyridinyl structure leading to the series of compounds presented in Table 3. Some others are methylenedioxy-substituted analogs differing from their corresponding methylenedioxy amphetamines by the addition of only a beta-ketone group (Table 4). Moreover, besides substituted 2-amino-1-phenyl-1-propanones, some 1-amino-1-phenyl-2-propanone derivatives are now emerging, including isoethcathinone and isopentedrone. All these compounds are chiral, and can exist in two stereoisomer forms. Aside from their usual trade names, substituted cathinones may be intentionally mislabeled and retailed under slang names as bath salts, plant food, or research chemicals and be labeled not for human consumption. They may be referred to by specific street names, such as meow-meow, MCAT, meph, subcoca-1, and so on, for mephedrone or by generic brand names as Energy 1, 2, or 3 (NRG1, 2, or 3), Blizzard, Blue silk, and Ivory snow among others. Qualitative analyses have been carried out on so called legal highs or NRG that have been obtained from different websites. They showed that: 1) the real composition of many of the products were found to differ markedly from information given to the purchaser, and 2) the majority of these products contained a mixture of substituted cathinones, ${ }^{1}$ which increased poisoning risk.

\section{Current and developing analytical methods for detection Immunochemistry}

As a general rule, immunoassay screening methodologies used to detect methamphetamines fail to detect cathinone derivatives but can give false positive reactions for some. ${ }^{2}$ We tested the cross-reactivity of some cathinones using the semi-quantitative AxSYM amphetamine/methamphetamine II assay that utilizes Fluorescence Polarization Immunoassay (FPIA) (Abbott Laboratories, Chicago, IL, USA). We evaluated the responses obtained from aqueous solutions of 14 substituted cathinones at three concentrations: $1 \mathrm{mg} / \mathrm{L}, 10 \mathrm{mg} / \mathrm{L}$, and $100 \mathrm{mg} / \mathrm{L}$. Even at $100 \mathrm{mg} / \mathrm{L}$, pentedrone, pentylone, $\alpha$-pyrrolidinovalerophenone (PVP), and methylenedioxypyrovalerone (MDPV) did not react with the test; the most sensitive cathinones that reacted in the assay at $10 \mathrm{mg} / \mathrm{L}$ had the least substitutions on the ethyl amine chain: ethylone, mephedrone, methylone, methedrone, and 4-methylethcathinone (MEC). A cross-reaction study with the nal von minden methamphetamine Drug-Screen ${ }^{\circledR}$ test (nal von minden $\mathrm{GmbH}$, Regensburg, Germany), confirmed the poor response of cathinones with these screening tests. Looking at these data obtained with marketed amphetamine/methamphetamine assays, even if cross-reactivity is chemical structure-dependent, a positive result is not expected in a user's urine, except perhaps in the context of massive intoxication. By contrast, it was recently shown that MDPV cross-reacts with the phencyclidine (PCP) immunoassay used in hospitals. ${ }^{3}$ Recently, in commercial enzyme-linked immunosorbent assays, eight cathinone derivatives among 30 designer drugs that were evaluated demonstrated cross-reactivity at concentrations at low as $0.15 \mathrm{mg} / \mathrm{L}$ when tested against the Randox Mephedrone/Methcathinone ELISA kit (RANDOX Toxicology, Crumlin, UK) recently developed for forensic specific cathinones screening in urine and blood specimens. ${ }^{4}$

\section{Gas chromatography-mass spectrometry}

The method of choice to rapidly identify substituted cathinones in powders remains gas liquid chromatography connected to electron-impact mass spectrometry (GC-MS). ${ }^{1,5,6}$ In our own experience, when we used a 5\% phenyl methylpolysiloxane fused-silica capillary column $(30 \mathrm{~m} \times 0.25 \mathrm{~mm} \times 0.25 \mu \mathrm{m})$, oven temperature ramped from $100^{\circ} \mathrm{C}$ (hold time: 1 minute) at $8^{\circ} \mathrm{C} /$ minute to $280^{\circ} \mathrm{C}(1.5$ minutes $)$, helium flow at $1 \mathrm{~mL} /$ minute, the 
Table I List of the most common substituted cathinones

\begin{tabular}{|c|c|}
\hline Usual names & Chemical name \\
\hline Amfepramone or diethylpropion & 2-diethylamino-I-phenyl-I-propanone \\
\hline Benzedrone or methylbenzylcathinone or 4-MBC & I-(4-methylphenyl)-2-benzylamino-I-propanone \\
\hline BMDB & 2-benzylamino-I-(3,4-methylenedioxyphenyl)-I-butanone \\
\hline BMDP or 3,4-MDBC & 2-benzylamino-I-(3,4-methylenedioxyphenyl)-I-propanone \\
\hline Brephedrone or 4-bromomethcathinone or 4-BMC & I-(4-bromophenyl)-2-(methylamino)-I-propanone \\
\hline Buphedrone & 2-(methylamino)-I-phenyl-I-butanone \\
\hline Bupropion & I-(3-chlorophenyl)-2-(tertbutylamino)-I-propanone \\
\hline Butylone or bk-MBDB & 2-(methylamino)-I-(3,4-methylenedioxyphenyl)-I-butanone \\
\hline Cathinone & 2-amino-I-phenyl-I-propanone \\
\hline Dibutylone or methylbutylone or bk-DMBDB & 2-(dimethylamino)-I-(3,4-methylenedioxyphenyl)-I-butanone \\
\hline Dimethylone or bk-MDDMA & I-(I,3-benzodioxol-5-yl)-2-(dimethylamino)-I-butanone \\
\hline Dimethylmethcathinone or 3,4-DMMC & I-(3,4-dimethylphenyl)-2-(methylamino)-I-propanone \\
\hline Ephedrone or methcathinone & 2-(methylamino)-I-(4ethylphenyl)-I-propanone \\
\hline Ethylbuphedrone or NEB & 2-(ethylamino)-I-phenyl-I-butanone \\
\hline Ethylcathinone or ethcathinone or ethylpropion & 2-(ethylamino)-I-phenyl-I-propanone \\
\hline Ethylmethcathinone or 4-EMC & 2-(methylamino)-I-phenyl-I-propanone \\
\hline Ethylone or bk-MDEA & 2-(ethylamino)-I-(3,4-methylenedioxyphenyl)-I-propanone \\
\hline Eutylone ou bk-EBDB & I-(I,3-benzodioxol-5-yl)-2-(ethylamino)-I-butanone \\
\hline Flephedrone or 4-fluoromethcathinone or 4-FMC & 2-(methylamino)-I-(4-fluorophenyl)-I-propanone \\
\hline Fluorocathinone or '-FC & 2-amino-I-(4-fluorophenyl)-I-propanone \\
\hline Fluoromethcathinone or 3-FMC & 2-(methylamino)-I-(3-fluorophenyl)-I-propanone \\
\hline Isoethcathinone & 2-(ethylamino)-I-phenyl-2-propanone \\
\hline Isopentedrone & 2-(methylamino)-I-phenyl-2-pentanone \\
\hline MDMPP & I-(3,4-methylenedioxyphenyl)-2-methyl-2-pyrrolidinyl-I-propanone \\
\hline MDPBP & I-(3,4-methylenedioxyphenyl)-2-(I-pyrrolidinyl)-I-butanone \\
\hline MDPPP & I-(3,4-methylenedioxyphenyl)-2-(I-pyrrolidinyl)-I-propanone \\
\hline MDPV or MDPK & I-(3,4-methylenedioxyphenol)-2-pyrrolidinyl-I-pentanone \\
\hline Mephedrone or 4-methylmethcathinone or 4-MMC & 2-(methylamino)-I-(4-methylphenyl)-I-propanone \\
\hline Metamfepramone or dimethylcathinone or dimethylpropion & 2-dimethylamino-I-phenyl-I-propanone \\
\hline Methedrone or 4-methoxymethcathinone or bk-PMMA & I-(4-methoxyphenyl)-2-(methylamino)-I-propanone \\
\hline Methylbuphedrone or 4Me-MABP or bk-N-methyl-4-MAB & 2-(methyllamino)-I-(4-methylphenyl)-I-butanone \\
\hline Methylethcathinone or 4-MEC & 2-(ethylamino)-I-(4-methylphenyl)-I-propanone \\
\hline Methylmethcathinone or 3-MMC & 2-(methylamino)-I-(3-methylphenyl)-I-propanone \\
\hline Methylone or MDMC or bk-MDMA & 2-methylamino-I-[3,4-methylenedioxyphenyl]-I-propanone \\
\hline MOPPP & $4^{\prime}$-methoxy- $\alpha$-pyrrolidinovalerophenone \\
\hline MPBP & I-(4-methylphenyl)-2-(I-pyrrolidinyl)-I-butanone \\
\hline MPHP & $4^{\prime}$-methyl- $\alpha$-pyrrolidinovalerophenone \\
\hline MPPP & 4'-methyl- $\alpha$-pyrrolidinovalerophenone \\
\hline Naphyrone & I-naphthalen-2-y|-2-pyrrolidin-I-yl-I-pentanone \\
\hline Propylbutylone or bk-PBDB & 2-(propylamino)-I-(3,4-methylenedioxyphenyl)-I-butanone \\
\hline Pentedrone or ethyl-methcathinone & 2-(methylamino)-I-phenyl-I-pentanone \\
\hline Pentylone & 2-(methylamino)-I-(3,4-methylenedioxyphenyl)-I-pentanone \\
\hline PBP & I-phenyl-2-(I-pyrrolidinyl)-I-butanone \\
\hline PEP & I-phenyl-2-(I-pyrrolidinyl)-I-heptanone \\
\hline PPP & I-phenyl-2-(I-pyrrolidinyl)-I-propanone \\
\hline PVP & I-phenyl-2-(I-pyrrolidinyl)-I-pentanone \\
\hline Pyrovalerone & II-(4-methylphenyl)-2-(I-pyrrolidinyl)-I-pentanone \\
\hline Trimethylmethcathinone or 2,4,5-TMMC & 2-(methylamino)-I-(2,4,5-trimethylphenyl)-I-propanone \\
\hline
\end{tabular}

total runtime was 25 minutes and the rank order (retention time) of the 14 analyzed cathinones was as follows: flephedrone $<$ metamfepramone $<$ ethcathinone $<$ mephedrone $<$ pentedrone $<$ amfepramone $<4$-MEC $<$ methedrone $<$ methylone $<$ PVP $<$ ethylone $<$ butylone $<$ pentylone $<$ MDPV. The selected mass spectrometry (MS) data that we collected in the literature and in our own data bank are summarized in Table 5 and permit the identification of the most common substituted cathinones. As a general rule, mass spectra show base peaks in the low mass and small or absent intensities for the molecular ions $(\mathrm{M}+)$. The massspectral fragmentation pattern of cathinone derivatives under electron impact conditions includes the formation of different 


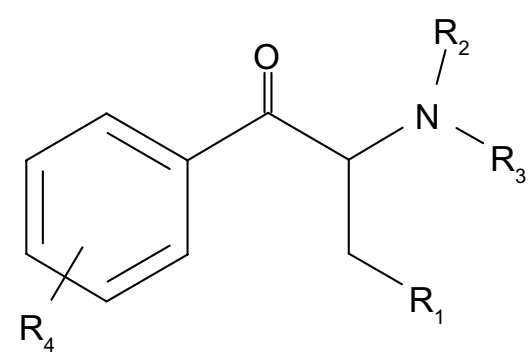

Figure I Chemical structure of synthetic cathinones.

iminium ions at $\mathrm{m} / \mathrm{z} 44,58,72,86$, and 100 . For cathinones with a pyrrolidine ring in the side chain, fragmentation leads to the formation of characteristic ions at $\mathrm{m} / \mathrm{z} 70,55,42$, and 41, results of the pyrrolidine ring degradation. The alternative cleavage reaction that is typical for aromatic ketones results in the formation

Table 2 Related structure of several alkylcathinones

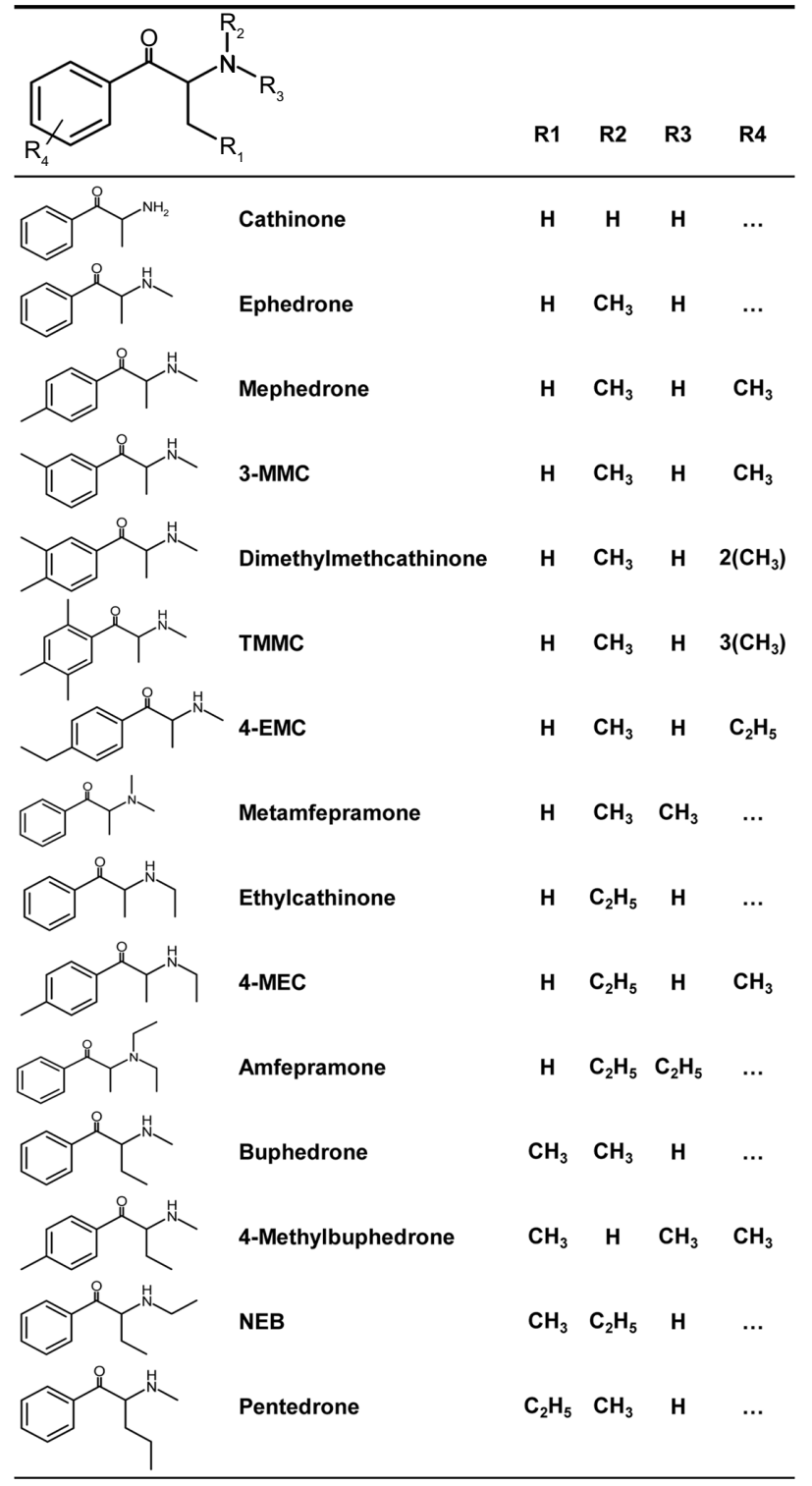

Abbreviations: MMC, mehylmethcathinone; TMMC, trimethylmethcathinone; EMC, ethylmethcathinone; MEC, methylethcathinone; NEB, ethylbuphedrone.
Table 3 Structure of pyrrolidinyl substituted cathinones

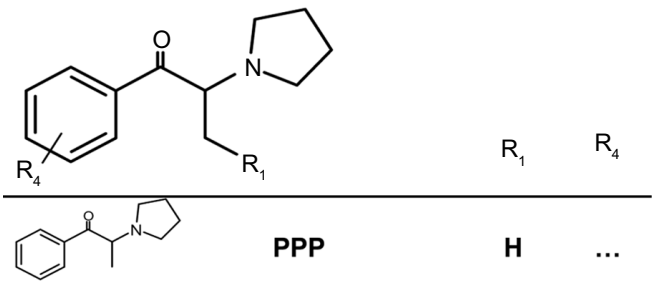<smiles>CCC(C(=O)c1ccccc1)N1CCCC1</smiles>

PBP

$\mathrm{CH}_{3} \quad \ldots$<smiles>CCCC(C(=O)c1ccccc1)N1CCCC1</smiles>

PVP

$\mathrm{C}_{2} \mathrm{H}_{5} \quad \ldots$<smiles>CCCCCC(C(=O)c1ccccc1)N1CCCC1</smiles><smiles>Cc1ccc(C(=O)C(C)N2CC3CCCC2C3)cc1</smiles>

MPPP

$\mathrm{C}_{4} \mathrm{H}_{9} \quad \ldots$<smiles>CCC(C(=O)c1ccc(C)cc1)N1CCCC1</smiles>

MPBP<smiles>CCCCC(C(=O)c1ccc(C)cc1)N1CCCC1CCC(C(=O)c1ccc(C)cc1)N1CCCC1</smiles>

Pyrovalerone

$\mathrm{C}_{2} \mathrm{H}_{5} \quad \mathrm{CH}_{3}$

MPHP

$\mathrm{C}_{3} \mathrm{H}_{7} \quad \mathrm{CH}_{3}$<smiles>COc1ccc(C(=O)C(C)N2CCCC2)cc1</smiles>

MOPPP

H $\mathrm{OCH}_{3}$<smiles>C=CCOC</smiles>

Naphyrone

$\mathrm{C}_{2} \mathrm{H}_{5} \mathbb{1}$<smiles>CC(C(=O)c1ccc2c(c1)OCO2)N1CCCC1</smiles>

MDPPP

$\mathrm{H}<-$<smiles>CCC(C(=O)c1ccc2c(c1)OCO2)N1CCCC1</smiles>

MDPBP

$\mathrm{CH}_{3}<-$<smiles>CC(C)C(C(=O)c1ccc2c(c1)OCO2)N1CCCC1CCC(C(=O)c1ccc2c(c1)OCO2)N1CCCC1</smiles>

MDPV

$\mathrm{C}_{2} \mathrm{H}_{5}<-$

MDMPP

Abbreviations: PPP, pyrrolidinopropiophenone; PBP, pyrrolidinobutyrophenone; PVP, pyrrolidinovalerophenone; PEP, pyrrolidinoenanthophenone; MPPP, methyl pyrrolidinopropiophenone; MOPPP, methoxy pyrrolidinopropiophenone; MDPBP, methylenedioxy pyrrolidinobutyrophenone; MDPV, methylenedioxypyrovalerone; MDMPP, methylenedioxy pyrrolidinopropiophenone.

of the product of decarboxylation, the phenyl cation (m/z 77). ${ }^{7}$ All isomers of fluoromethcathinone show significant fragments at $\mathrm{m} / \mathrm{z} 95$ and $\mathrm{m} / \mathrm{z} 123$; these correspond to the fluorophenyl cation and fluorobenzoyloxy cation, respectively. ${ }^{8}$ The limit of quantification in biologic fluids for the GC-MS method developed by Torrance and Cooper in 2010 was $100 \mu \mathrm{g} / \mathrm{L} .{ }^{9}$ This value is acceptable in fatal cases but appears inadequate to measure concentrations in user's blood. 
Table 4 Chemical structure of methylenedioxy amphetamines and cathinones

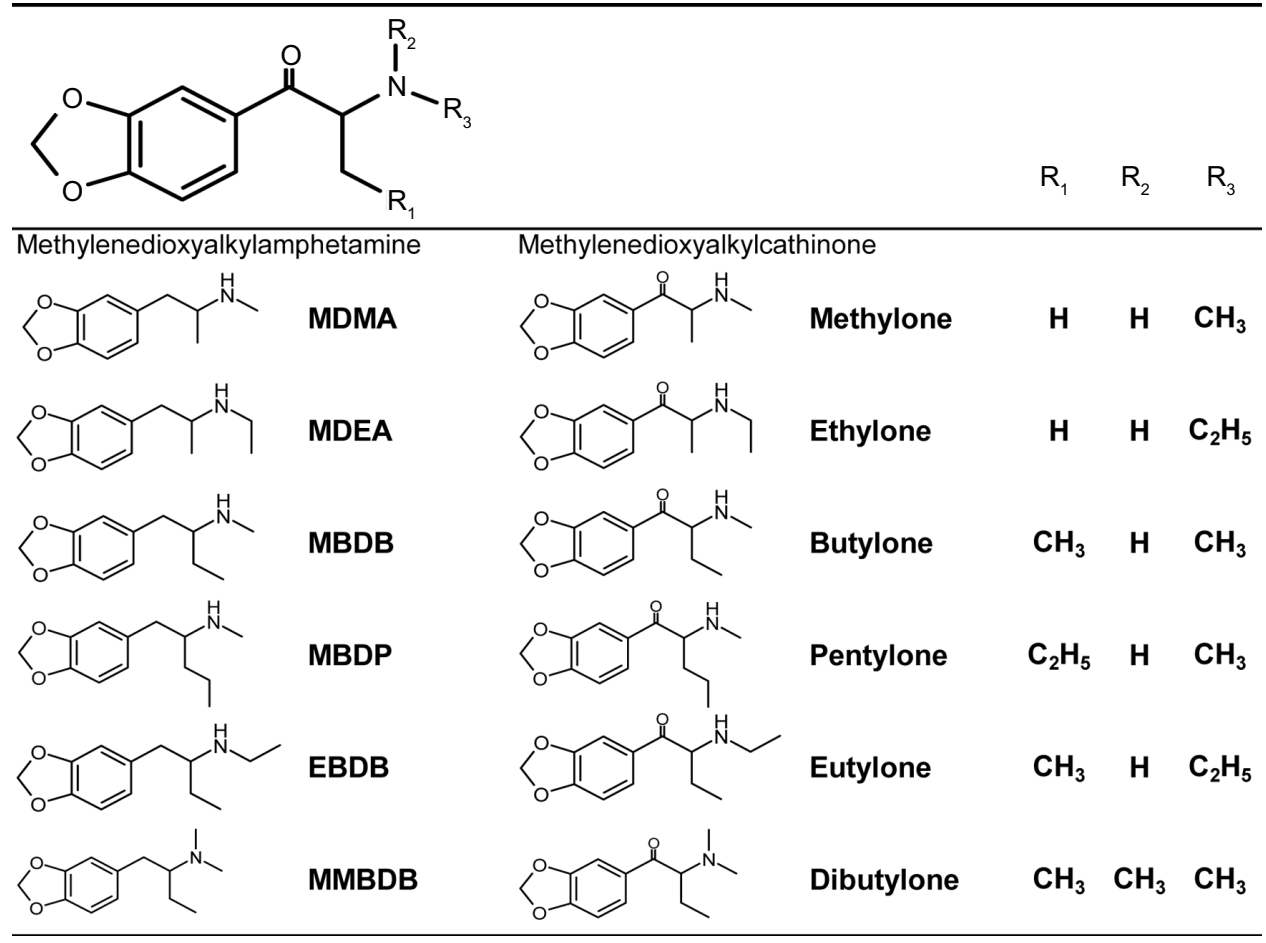

Abbreviations: MDMA, methylenedioxymethylamphetamine; MDEA, methylenedioxyethylamphetamine; MBDB, methylbenzodioxolylbutanamine; MBDP, methylbenzodioxolylpentanamine; EBDB, ethylbenzodioxolylbutanamine; MMBDB, dimethylbenzodioxolylbutanamine.

\section{Liquid chromatography-mass spectrometry}

Different liquid chromatography-tandem-mass spectrometry (LC-MS-MS) screening or semi-quantitative/quantitative methods have been published to identify and quantify substituted cathinones in urine, oral fluid, live and post-mortem whole blood, and post mortem tissues, ${ }^{10-14}$ or using dried blood spots. ${ }^{15}$ More recently, rapid screening using direct analysis in real time mass spectrometry (DART-MS) or using portable mass-spectrometer equipped with desorption electrospray ionization (DESI-MS) shortened the time of the sensitive and selective examination of substituted cathinones from various substrates. ${ }^{16,17} \mathrm{~A}$ classic reverse phase $\mathrm{C} 18$ or a phenyl column is typically used for the chromatographic separation prior to analysis by LC-tandem MS using electrospray positive ionization multiple reaction monitoring (MRM) mode. ${ }^{18} \mathrm{MRM}$ transitions for cathinones are presented in Table 6. For all substances, the dominant Q1 (first quadripole) ions were the protonated molecular ions $\left([\mathrm{M}+\mathrm{H}]^{+}\right)$. The product ion $\left(\left[\mathrm{M}+\mathrm{H}-\mathrm{H}_{2} \mathrm{O}\right]^{+}\right)$is generally the most abundant in Q3, except for amfepramone. Cathinones with unsubstituted ring structures produced $\mathrm{m} / \mathrm{z} 105$ ions $\left([\mathrm{Ph}-\mathrm{C} \equiv \mathrm{O}]^{+}\right)$in significant abundance. For all substances, at least two product ions of acceptable abundance can be obtained. ${ }^{19}$ In order to complete targeted LS-MS-MS screening, LC coupled to high resolution quadripole time-of-flight MS (LC-Q-TOF-MS) methods have been developed to identify new structures of cathinones or fragmented ions in "legal highs" ${ }^{20,21}$ or biological samples. ${ }^{22,23}$ Zuba described that under electrospray ionization (ESI)-Q-TOF-MS conditions, the loss of water and $\alpha$-cleavage of the amine end are the most characteristic features.$^{20}$ For the 3,4-methylenedioxy cathinone derivatives, the loss of the methylenedioxy group $\mathrm{CH}_{4} \mathrm{O}_{2}$ (48.02) and the formation of the cation $\left[\mathrm{M}+\mathrm{H}-\mathrm{CH}_{4} \mathrm{O}_{2}\right]^{+}$are observed. ${ }^{21}$ The limits of quantification for the assay of substituted cathinones in serum using an electrospray ionization source in positive polarity are of the order of $10 \mu \mathrm{g} / \mathrm{L}$ with a linear dynamic range of 10 to $500 \mu \mathrm{g} / \mathrm{L}$. Accordingly, LC-MS-MS is the only method that presents sufficient sensibility to quantify substituted cathinones in biological fluids.

\section{Extraction procedures for quantification in biological samples}

Different sample preparations are proposed including basic liquid-liquid extraction ${ }^{24}$ and solid-phase extraction methods. ${ }^{25}$ Consistent with our personal data, commercially available liquid-liquid extraction tubes, such as Toxi.tubes $\mathrm{A}^{\circledR}$ (Agilent Technologies, Santa Clara, CA, USA), can be considered as an alternate. For LC-MS-MS, a single precipitation step of methanol denatured protein by centrifugation was recommended by Sørensen before injection in the liquid chromatograph system. ${ }^{19}$ 
Table 5 Gas-chromatography mass spectrometry identification of substituted cathinones

\begin{tabular}{|c|c|c|c|c|}
\hline \multirow[t]{2}{*}{ Name } & \multirow{2}{*}{$\begin{array}{l}\text { Molecular } \\
\text { formula }\end{array}$} & \multicolumn{2}{|c|}{ GC-MS identification (electronic impact) } & \multirow[t]{2}{*}{ Reference } \\
\hline & & Base peak & Other peaks & \\
\hline Amfepramone & $\mathrm{C}_{13} \mathrm{H}_{19} \mathrm{NO}$ & 100 & $44,72,206$ & $*$ \\
\hline Benzedrone & $\mathrm{C}_{17} \mathrm{H}_{19} \mathrm{NO}$ & 91 & $119,146,236$ & $*$ \\
\hline BMDB & $\mathrm{C}_{18} \mathrm{H}_{19} \mathrm{NO}_{3}$ & 91 & $65,121,148$ & $*$ \\
\hline BMDP & $\mathrm{C}_{17} \mathrm{H}_{17} \mathrm{NO}_{3}$ & 91 & 65,134 & * \\
\hline Brephedrone & $\mathrm{C}_{10} \mathrm{H}_{12} \mathrm{BrNO}$ & 58 & $155,183,75$ & $*$ \\
\hline Buphedrone & $\mathrm{C}_{11} \mathrm{H}_{15} \mathrm{NO}$ & 72 & 77,105 & 20 \\
\hline Bupropion & $\mathrm{C}_{13} \mathrm{H}_{18} \mathrm{CINO}$ & 44 & $75,100,139$ & $*$ \\
\hline Butylone & $\mathrm{C}_{12} \mathrm{H}_{15} \mathrm{NO}_{3}$ & 72 & 121,149 & 6 \\
\hline Cathinone & $\mathrm{C}_{9} \mathrm{H}_{11} \mathrm{NO}$ & 44 & $5 \mathrm{I}, 77,105$ & $*$ \\
\hline Dibutylone & $\mathrm{C}_{13} \mathrm{H}_{17} \mathrm{NO}_{3}$ & 86 & 121,149 & $*$ \\
\hline Dimethylmethcathinone & $\mathrm{C}_{12} \mathrm{H}_{17} \mathrm{NO}$ & 58 & $77,105,133$ & $*$ \\
\hline Dimethylone & $\mathrm{C}_{12} \mathrm{H}_{15} \mathrm{NO}_{3}$ & 72 & $91,121,149$ & 96 \\
\hline Ephedrone & $\mathrm{C}_{10} \mathrm{H}_{13} \mathrm{NO}$ & 58 & $51,56,77$ & $*$ \\
\hline Ethcathinone & $\mathrm{C}_{11} \mathrm{H}_{15} \mathrm{NO}$ & 72 & 44,105 & 5 \\
\hline Ethylbuphedrone & $\mathrm{C}_{12} \mathrm{H}_{17} \mathrm{NO}$ & 86 & 77,105 & $*$ \\
\hline Ethylone & $\mathrm{C}_{12} \mathrm{H}_{15} \mathrm{NO}_{3}$ & 72 & $121,149,44$ & 96 \\
\hline Eutylone & $\mathrm{C}_{13} \mathrm{H}_{17} \mathrm{NO}_{3}$ & 72 & $91,121,149$ & $*$ \\
\hline Flephedrone & $\mathrm{C}_{10} \mathrm{H}_{12} \mathrm{FNO}$ & 58 & $75,95,123,182$ & 97 \\
\hline 3-FMC & $\mathrm{C}_{10} \mathrm{H}_{12} \mathrm{FNO}$ & 58 & $75,95,123$ & 97 \\
\hline MDPBP & $\mathrm{C}_{15} \mathrm{H}_{19} \mathrm{NO}_{3}$ & 112 & 149 & 98 \\
\hline MDPPP & $\mathrm{C}_{14} \mathrm{H}_{17} \mathrm{NO}_{3}$ & 98 & $121,149,178$ & 99 \\
\hline MDPV & $\mathrm{C}_{16} \mathrm{H}_{21} \mathrm{NO}_{3}$ & 126 & 149 & 6 \\
\hline 4-MEC & $\mathrm{C}_{12} \mathrm{H}_{17} \mathrm{NO}$ & 72 & 119,91 & 100 \\
\hline Mephedrone & $\mathrm{C}_{11} \mathrm{H}_{15} \mathrm{NO}$ & 58 & $91,119,162$ & 5 \\
\hline Metamfepramone & $\mathrm{C}_{11} \mathrm{H}_{15} \mathrm{NO}$ & 72 & $51,56,70,77$ & $*$ \\
\hline Methedrone & $\mathrm{C}_{11} \mathrm{H}_{15} \mathrm{NO}_{2}$ & 58 & 77,135 & 101 \\
\hline Methylbuphedrone & $\mathrm{C}_{12} \mathrm{H}_{17} \mathrm{NO}$ & 72 & $91,119,57$ & $*$ \\
\hline Methylethcathinone & $\mathrm{C}_{12} \mathrm{H}_{17} \mathrm{NO}$ & 72 & $44,91,119$ & $*$ \\
\hline Methylone & $\mathrm{C}_{11} \mathrm{H}_{13} \mathrm{NO}_{3}$ & 58 & $91,121,149$ & 6 \\
\hline MOPPP & $\mathrm{C}_{14} \mathrm{H}_{19} \mathrm{NO}_{2}$ & 98 & $107,135,233$ & 99 \\
\hline MPBP & $\mathrm{C}_{15} \mathrm{H}_{21} \mathrm{NO}$ & 112 & || $9,9 \mid$ & 102 \\
\hline MPHP & $\mathrm{C}_{17} \mathrm{H}_{25} \mathrm{NO}$ & 140 & & 77 \\
\hline MPPP & $\mathrm{C}_{14} \mathrm{H}_{19} \mathrm{NO}$ & 98 & $56,91,119,216$ & 72 \\
\hline Naphyrone & $\mathrm{C}_{19} \mathrm{H}_{23} \mathrm{NO}$ & 126 & 84,155 & 103 \\
\hline NEB & $\mathrm{C}_{12} \mathrm{H}_{17} \mathrm{NO}$ & 86 & $77,58,105$ & $*$ \\
\hline PBP & $\mathrm{C}_{14} \mathrm{H}_{19} \mathrm{NO}$ & 112 & 77 & 80 \\
\hline Pentedrone & $\mathrm{C}_{12} \mathrm{H}_{17} \mathrm{NO}$ & 86 & $44,77,105$ & 104 \\
\hline Pentylone & $\mathrm{C}_{13} \mathrm{H}_{17} \mathrm{NO}_{3}$ & 86 & 44,149 & 104 \\
\hline PPP & $\mathrm{C}_{13} \mathrm{H}_{17} \mathrm{NO}$ & 98 & $56,77,105$ & 72 \\
\hline PVP & $\mathrm{C}_{15} \mathrm{H}_{21} \mathrm{NO}$ & 126 & $77,84,232$ & $*$ \\
\hline Pyrovalerone & $\mathrm{C}_{16} \mathrm{H}_{23} \mathrm{NO}$ & 126 & $91,119,135$ & * \\
\hline
\end{tabular}

\section{Note: *Personal data.}

Abbreviations: BMDB, benzylaminomethylenedioxyphenylbutanone; BMDP, benzylaminomethylenedioxyphenylpropanone; FMC, fluoromethcathinone; MDPBP, methylenedioxypyrrolidinobutyrophenone; MDPPP, methylenedioxypyrrolidinopropiophenone; MDPV, methylenedioxyPyrovalerone; MEC, methylethcathinone; MOPPP, methoxy pyrrolidinopropiophenone; MPBP, methylpyrrolidinobutyrophenone; MPHP, methylpyrrolidinohexanophenone; MPPP, methylpyrrolidinopropiophenone; NEB, ethylbuphedrone; PBP, pyrrolidinobutyrophenone; PPP, $\alpha$-pyrrolidinopropiophenone; PVP, $\alpha$-pyrrolidinovalerophenone.

\section{Experimental pharmacology and neuropharmacology} In vitro

As with amphetamines or cocaine, substituted cathinones act as central nervous system stimulants, via increasing synaptic concentration of catecholamines, such as dopamine, serotonin, and norepinephrine. These monoamines are released into the synapse where their concentrations are regulated, at least in part, by reuptake proteins (dopamine [DAT], serotonin [SERT], norepinephrine [NET] transporters). ${ }^{26}$ In uptake and release assays performed in rat synaptosomes or in HEK293 cells that stably expressed human SERT, NET, and DAT, cathinone derivatives are able to strongly inhibit these uptake transporters, but may also stimulate release of the three monoamines from intracellular stores. Nevertheless, considerable differences have been found in the pharmacology of the different substituted cathinones in vitro. Mephedrone, methylone, ethylone, butylone, and 
Table 6 Liquid chromatography-tandem mass spectrometry identification of substituted cathinones

\begin{tabular}{|c|c|c|c|c|c|}
\hline \multirow[t]{2}{*}{ Name } & \multirow{2}{*}{$\begin{array}{l}\text { Molecular } \\
\text { formula }\end{array}$} & \multirow{2}{*}{$\begin{array}{l}\text { Molecular } \\
\text { weight }\end{array}$} & \multicolumn{2}{|c|}{ Multiple reaction monitoring (MRM) transitions } & \multirow[t]{2}{*}{ Reference } \\
\hline & & & Precursor ion $[\mathrm{m} / \mathrm{z}]$ & Product ion $[\mathrm{m} / \mathrm{z}]$ & \\
\hline Amfepramone & $\mathrm{C}_{13} \mathrm{H}_{19} \mathrm{NO}$ & 205,30 & 206,1 & $105 ; 133 ; 100,1 ; 72$ & 19 \\
\hline BMDB & $\mathrm{C}_{18} \mathrm{H}_{19} \mathrm{NO}_{3}$ & 297,30 & 298,1 & 280,$13 ; 250,1 ; 191 ; 148$ & * \\
\hline BMDP & $\mathrm{C}_{17} \mathrm{H}_{17} \mathrm{NO}_{3}$ & 283,30 & 284,1 & $266, I ; 236, I ; 134, I$ & * \\
\hline Buphedrone & $\mathrm{C}_{11} \mathrm{H}_{15} \mathrm{NO}$ & 177,24 & 178,1 & I60,I; 91,1;77,I & 20 \\
\hline Bupropion & $\mathrm{C}_{13} \mathrm{H}_{18} \mathrm{CINO}$ & 239,74 & 240 & 185 & 18 \\
\hline Butylone & $\mathrm{C}_{12} \mathrm{H}_{15} \mathrm{NO}_{3}$ & 221,25 & 222 & $174 ; 204,3 ; 191 ; 161$ & 19 \\
\hline Cathinone & $\mathrm{C}_{9} \mathrm{H}_{11} \mathrm{NO}$ & 149,19 & 150 & $|32,| ;|1| 7,2$ & 24 \\
\hline Dibutylone & $\mathrm{C}_{13} \mathrm{H}_{17} \mathrm{NO}_{3}$ & 235,28 & 236,1 & 191,$04 ; 161,05 ; 86,36$ & $*$ \\
\hline Dimethylcathinone & $\mathrm{C}_{11} \mathrm{H}_{15} \mathrm{NO}$ & 177,24 & I78, I & 105,$1 ; 133,1$ & 11 \\
\hline Dimethylmethcathinone & $\mathrm{C}_{12} \mathrm{H}_{17} \mathrm{NO}$ & 191,27 & 192,05 & $174 ; 159,158$ & 24 \\
\hline Ephedrone & $\mathrm{C}_{10} \mathrm{H}_{13} \mathrm{NO}$ & 163,22 & 164,2 & $|46| ;,|3|$ & 24 \\
\hline Ethcathinone & $\mathrm{C}_{11} \mathrm{H}_{15} \mathrm{NO}$ & 177,24 & 178,1 & $160 ; 132,1$ & 24 \\
\hline Ethylone & $\mathrm{C}_{12} \mathrm{H}_{15} \mathrm{NO}_{3}$ & 221,25 & 222 & $174 ; 204,3$ & 24 \\
\hline Flephedrone & $\mathrm{C}_{10} \mathrm{H}_{12} \mathrm{FNO}$ & $|8|, 2 \mid$ & 182,2 & $164 ; 149$ & 24 \\
\hline 3-FMC & $\mathrm{C}_{10} \mathrm{H}_{12} \mathrm{FNO}$ & $|8|, 2 \mid$ & 182,2 & $164 ; 149$ & 24 \\
\hline MDPPP & $\mathrm{C}_{14} \mathrm{H}_{17} \mathrm{NO}_{3}$ & 247,28 & 248 & 98,$1 ; 147$ & 24 \\
\hline MDPV & $\mathrm{C}_{16} \mathrm{H}_{21} \mathrm{NO}_{3}$ & 275,35 & 276,2 & $|26| ;,|35,| ;|49,9 ;| 75, \mid$ & $*$ \\
\hline MDPBP & $\mathrm{C}_{15} \mathrm{H}_{19} \mathrm{NO}_{3}$ & 261,32 & 262,2 & II 2,$2 ;|49|$, & 11 \\
\hline Mephedrone & $\mathrm{C}_{11} \mathrm{H}_{15} \mathrm{NO}$ & 177,24 & 178,2 & 160,$2 ; 145 ; 143,9$ & 24 \\
\hline Metamfepramone & $\mathrm{C}_{11} \mathrm{H}_{15} \mathrm{NO}$ & 177,24 & 178,1 & 105,$1 ; 77,1 ; 72,1$ & $*$ \\
\hline Methedrone & $\mathrm{C}_{11} \mathrm{H}_{15} \mathrm{NO}_{2}$ & 193,24 & 194,1 & 175,$9 ; 160,9 ; 146$ & 24 \\
\hline Methylethcathinone & $\mathrm{C}_{12} \mathrm{H}_{17} \mathrm{NO}$ & 191,27 & 192,2 & I74,3; I44,I; 91,। & 24 \\
\hline Methylone & $\mathrm{C}_{11} \mathrm{H}_{13} \mathrm{NO}_{3}$ & 207,23 & 208 & 159,$9 ; 190,2 ; 132,1$ & 24 \\
\hline Naphyrone & $\mathrm{C}_{19} \mathrm{H}_{23} \mathrm{NO}$ & 281,39 & 282,1 & $|4|, \mid ; 211 ; 127,7$ & 24 \\
\hline Pentedrone & $\mathrm{C}_{12} \mathrm{H}_{17} \mathrm{NO}$ & 191,27 & 192,18 & 174,$1 ; 132,2 ; 91,1$ & $*$ \\
\hline Pentylone & $\mathrm{C}_{13} \mathrm{H}_{17} \mathrm{NO}_{3}$ & 235,28 & 236,1 & $188 ; 218 ; 175$ & 24 \\
\hline PPP & $\mathrm{C}_{13} \mathrm{H}_{17} \mathrm{NO}$ & 203,28 & 204,1 & $105, \mathrm{I} ; \mathrm{I} 32,9 ; 98,2$ & 24 \\
\hline PVP & $\mathrm{C}_{15} \mathrm{H}_{21} \mathrm{NO}$ & 231,33 & 232,21 & 91,$1 ; 77,1 ; 105,1 ; 126,1$ & $*$ \\
\hline Pyrovalerone & $\mathrm{C}_{16} \mathrm{H}_{23} \mathrm{NO}$ & 245,36 & 246,1 & I05,I; I74,9; 9I,I & 24 \\
\hline
\end{tabular}

Note: *Personal data.

Abbreviations: BMDB, benzylaminomethylenedioxyphenylbutanone; BMDP, benzylaminomethylenedioxyphenylpropanone; FMC, fluoromethcathinone; MDPPP, methylenedioxypyrrolidinopropiophenone; MDPV, methylenedioxypyrovalerone; MDPBP, methylenedioxypyrrolidinobutyrophenone; PPP, $\alpha$-pyrrolidinopropiophenone; PVP, $\alpha$-pyrrolidinovalerophenone.

4-fluoromethcathinone (FMC) are relatively non-selective transporter substrates that are fully efficacious in the release assays. ${ }^{27,28}$ Ethylone acts as non-selective DAT (half maximal inhibitory concentration $\left[\mathrm{IC}_{50}\right]=2.5 \mu \mathrm{M}$ ), SERT $(4.5 \mu \mathrm{M})$, and NET $(2.5 \mu \mathrm{M})$ inhibitors similar to cocaine. Methylone inhibits the activities of DAT $(4.8 \mu \mathrm{M})$, SERT $(15.5 \mu \mathrm{M})$, and NET $(0.5 \mu \mathrm{M})$ but not $\gamma$ - $\alpha$ minobutyric acid (GABA) transporter-1. ${ }^{29,30}$ Eshleman et al found that 4-FMC was an efficient releaser of dopamine, effective from $10 \mathrm{nM}$, as potent as mephedrone, but more potent than methylone. ${ }^{28}$ These substituted cathinones are also serotonin releasers. Comparing the substituted methcathinone efficacies to those of methamphetamine on SERT, mephedrone, and methylone had similar potencies to those of methamphetamine, while butylone and 4-FMC were less efficacious. With respect to NET, methamphetamine, 4-FMC, mephedrone, and methylone elicited a lower release of norepinephrine. ${ }^{28}$

In contrast, pyridinyl cathinones produce no dopamine or serotonin efflux but act as specific potent blockers of
DAT and NET. ${ }^{27,29,30}$ Pyrovalerone and MDPV exhibited very high affinity for the DAT in the low nanomolar range (30 $\mathrm{nM} \pm 5 \mathrm{nM}$ and $10 \mathrm{nM} \pm 2 \mathrm{nM}$, respectively) and NET (60 $\mathrm{nM} \pm 5 \mathrm{nM}$ and $80 \mathrm{nM} \pm 2 \mathrm{nM}$, respectively) and poor affinity for SERT in the micromolar range $(4.97 \pm 0.03 \mu \mathrm{M}$ and $2.86 \pm 0.1 \mu \mathrm{M}$ respectively). ${ }^{29}$ In 2013, Eshleman et al determined that naphyrone had high affinities for DAT (11 nM), SERT (15 nM), and NET (59 nM), high potency for uptake inhibition, and no drug-induced substrate release. ${ }^{28}$ Furthermore, pyrovalerone and MDPV were the most potent DAT inhibitors $\left(\mathrm{IC}_{50}=35 \mathrm{nM}\right.$ and $31 \mathrm{nM}$, respectively) and $\operatorname{NET}\left(\mathrm{IC}_{50}=43 \mathrm{nM}\right.$ and $44 \mathrm{nM}$, respectively) among all of the drugs studied by Simmler et al, ${ }^{29}$ including other cathinones, amphetamines, and cocaine. In the short term, whereas some cathinones, such as mephedrone, behave as dopamine-releasing agents (depolarizing current) similar to methamphetamine and may be categorized in methamphetamine-like releasers, some others, such as MDPV, act as dopamine-reuptake inhibitors (hyperpolarizing current) similar to cocaine (cocaine-like 
monoamine reuptake inhibitors). ${ }^{31,32}$ Additionally, substituted cathinones have no affinity for dopamine receptors and act as low potency serotonin (5HT)1A receptor partial agonists or 5HT2A/5HT2C antagonists. ${ }^{28}$

\section{In vivo}

After acute administration, cathinone derivatives share actions on central dopamine systems involved in the regulation of behavioral reinforcement, motor coordination, and thermoregulation. ${ }^{33}$ In 2012, Marusich et al concluded that in vivo all cathinones caused increased locomotor activity, with different cathinones showing different potencies, magnitudes of stimulation, and duration of action. ${ }^{32} \mathrm{MDPV}$, mephedrone, and 3-FMC produced the most pronounced initial stimulation similar to cocaine or methamphetamine, whereas methedrone produced the weakest initial stimulation. Oral administration of methylone ( $15 \mathrm{mg} / \mathrm{kg}$ and $30 \mathrm{mg} / \mathrm{kg}$ ) induced a dose-dependent increase in locomotor activity in rats. ${ }^{34}$ Cathinone $1 \mathrm{mg} / \mathrm{kg}$ or $4 \mathrm{mg} / \mathrm{kg}$, mephedrone $10 \mathrm{mg} / \mathrm{kg}$, and 3,4-methylenedioxy-Nmethylamphetamine MDMA $10 \mathrm{mg} / \mathrm{kg}$ caused similar hyperactivity in rats with evidence of locomotor sensitization following intermittent dosing with cathinone and mephedrone. ${ }^{35} \mathrm{MDPV}$ and naphyrone produced locomotor stimulant effects that lasted much longer than those of cocaine or methamphetamine. ${ }^{36}$ Moreover, stimulation of motor activity following administration of a wide range of MDPV doses ( $1 \mathrm{mg} / \mathrm{kg}$ to $30 \mathrm{mg} / \mathrm{kg}$ ) was affected by ambient temperature; ie, was potentiated in warm ambient temperature. ${ }^{37}$ By contrast, MDPV was interpreted to be a less potent disruptor of thermoregulation compared to methamphetamine..$^{38}$ Consistent with locomotor activation, substituted cathinones may produce hyperactivity, ataxia, convulsions, and stereotyped movements. ${ }^{32}$ They may also inhibit food intake in a less potent way than amphetamine. ${ }^{39}$

After a binge-like regimen of mephedrone and methylone, long-term changes in either neurochemistry or cognitive function have been observed in rodents with some variances depending on the product used. Mephedrone reduced working memory performance but did not affect neurotransmitter levels while methylone had little effect on behavior but produced a widespread depletion of serotonin levels in rats. Nevertheless, some discrepancies have been noticed among species since methylone did not cause significant change in serotonin level in mice. Accordingly, animal models have to be considered with caution when screening these psychoactive drugs of abuse. ${ }^{33}$

All cathinone derivatives are chiral and can exist in two stereoisomer forms that may differ in their pharmacological potencies. For instance, the S-isomer of methcathinone exhibits stronger central nervous system stimulating effects than its R-enantiomer. ${ }^{40}$

In animal models of addiction, cathinone demonstrated reinforcing potential. In rats trained to discriminate amphetamine from saline, cathinone and methcathinone resulted in stimulus generalization with methcathinone being the most potent; ${ }^{40}$ rhesus monkeys that were previously trained to selfadministrate cocaine, did not discriminate between cathinone and cocaine ${ }^{41}$ in a taste aversion test procedure used by Goudie in 1987, cathinone was less potent than amphetamine; ${ }^{42}$ and cathinone was equipotent to d-amphetamine in rats trained to discriminate the stimulus induced by the administered drug in a two-lever, food-motivated operant task..$^{43}$ In rats, MDPV, methylone, mephedrone, naphyrone, flephedrone, and butylone fully substituted for the discriminative stimulus effects of cocaine and methamphetamine. ${ }^{36}$ In rats trained to self-administer MDPV or methamphetamine, dose-substitution studies demonstrated that behavior was sensitive to dose for both drugs, but MDPV showed greater potency and efficacy than methamphetamine. ${ }^{38}$ In mice trained to discriminate $0.3 \mathrm{mg} / \mathrm{kg}$ MDPV from saline, cumulative doses of MDPV, MDMA and methamphetamine fully substituted for the MDPV training stimulus. In a study evaluating the abuse potential of MDPV by assessing its ability to support intravenous self-administration $(0.05 \mathrm{mg} / \mathrm{kg}$ to 0.2 $\mathrm{mg} / \mathrm{kg}$ ) and to lower thresholds for intracranial self-stimulation, MDPV had reinforcing properties. ${ }^{44}$ These rodent studies suggest that, like amphetamines, cathinone derivatives may be able to induce tolerance and dependence.

\section{Human use of substituted cathinones \\ Modalities of administration}

Substituted cathinones are most commonly nasally insufflated or orally ingested. Rectal administration, intramuscular or intravenous injection, and smoking or inhalation, have also been reported. Among 362 patients admitted to Texas poison centers during 2010-2011, the route of exposure was $47.8 \%$ by inhalation alone and $28.7 \%$ by ingestion alone. ${ }^{45}$ The typical dose range varies between the different cathinone derivatives. According to Erowid ${ }^{46}$ or Drugs-Forum ${ }^{47}$ websites, where users are invited to begin with a small dose then to gradually increase the dose, a typical first time oral dose of mephedrone or methylone ranges between $50 \mathrm{mg}$ and $100 \mathrm{mg}$; a dose of $150-250 \mathrm{mg}$ seems to be the usual dose in experienced users. Sumnall and Wooding ${ }^{48}$ reported that a light effect is obtained with an oral $25-100 \mathrm{mg}$, while a strong effect requires a higher dose of 125-250 mg. Insufflating doses are lower, ranging 
between 15-25 mg for a light effect to 75-125 $\mathrm{mg}$ for a strong effect. In addition, 80-120 mg of butylone and 20-100 mg of buphedrone are described as common oral doses. By contrast, users reported lower oral doses of MDPV or naphyrone between 5-30 $\mathrm{mg}$ and $10-50 \mathrm{mg}$, respectively.

\section{Recreational effects}

In humans, substituted cathinones have stimulant and entactogenic properties. Desired or "pleasant" effects most often described by users of synthetic cathinones include euphoria, intensification of sensory senses, increased sociability, increased energy, mental stimulation, empathy connection, openness, increased sensory perception, decreased inhibition, and sexual arousal. ${ }^{49}$

\section{Acute and chronic physical and psychological adverse/toxic effects}

For the 51 adolescent exposures reported to Texas poison centers, the medical outcome was known or suspected to be serious in $74.5 \% .{ }^{45}$ Physical signs of synthetic cathinone intoxication are characteristically associated with a sympathomimetic toxidrome with the most common feature being agitation in more than $50 \%$ of users. Other common features include tachycardia, heart palpitation, arrhythmia, increased blood pressure, capillary dilatation, and hemorrhage. Patients can also display headache, pupil dilatation, nausea/vomiting, suppressed appetite, bruxism, hyperthermia, dehydration, hot flushes, sweating, blue/cold extremities, and seizures. ${ }^{50}$ In 15 patients admitted to an emergency department following mephedrone use, the pattern of clinical toxicity included agitation in $53 \%$, tachycardia in $40 \%$, systolic hypertension in $20 \%$, and seizures in $20 \%{ }^{51}$ In overdose patients, physical manifestations range from severe hyperthermia, rhabdomyolysis, hyponatremia, acidosis, ${ }^{52}$ and seizures to those as severe as stroke, cerebral edema, cardiorespiratory collapse, myocardial infarction, multiple organ failure, and death. A case of severe neurologic toxicity and hyponatremia, followed by rhabdomyolysis, and consistent serotonin toxicity related to ethcathinone and methylone poisoning was reported in 2012. ${ }^{53}$ Several cases of myocardial infarction and mephedrone related myocarditis have been reported. ${ }^{54,55}$ Levine et al reported three cases of acute compartment syndromes (decreased tissue perfusion) attributed to synthetic cathinones (PVP, MDPV) with complete recovery in two patients; one patient remained in renal failure and continued to receive hemodialysis 5 months later. ${ }^{56}$ In a fatal case related to the consumption of methylone, steatosis of the heart muscle, congenital heart disease, and bronchial asthma could have been the predisposing factors for sudden cardiac death that occurred in the presence of methylone. ${ }^{57}$ Among 62 mephedrone young victims collected in the UK National Programme on Substance Abuse Deaths database, mephedrone alone was identified at postmortem on eight occasions. ${ }^{58}$

Behavioral effects include insomnia, confusion, agitation, panic attack, anxiety, severe paranoia, hallucinations, psychosis, suicidal ideation, self-mutilation, and aggressive, violent, and self-destructive behavior. ${ }^{59}$ White matter abnormalities with greatest severity of damage underlying executive motor areas have been observed in patients with a distinctive extrapyramidal syndrome due to intravenous ephedrone abuse. ${ }^{60}$ Moreover, ephedrone is synthesized from ephedrine or pseudoephedrine by potassium permanganate oxidation and there is a risk for manganese-induced extrapyramidal system damage including rigidity, hypokinesia, gait disorders, and hallucinations. ${ }^{61}$ In addition, the binge use of cathinone drugs may result in the development of the syndrome of excited delirium, including extreme agitation, violent behavior, confused speech, paranoia, and hallucinations. ${ }^{62}$

As a remark, nasal pain or bleeding is an associated local effect related to the irritant properties of mephedrone administered by the nasal route..$^{50}$

\section{Addictive potential}

The potency of abused drugs to activate the brain reward circuitry (dopamine system) increases the risk of potential for abuse and addiction in humans. In contrast, a relative activation of the serotonin system would be linked to a reduction in abuse potential. ${ }^{29,63-65}$ Thus, DAT/SERT inhibition ratio and dopamine/serotonin release potency have been proposed to predict the psychostimulant effect in humans. Mephedrone induced strong feelings of craving in most users ${ }^{66}$ and multiple cases of mephedrone dependence have been described in the medical literature. ${ }^{67}$ In a Scottish survey carried out prior to the classification of mephedrone, $4.4 \%$ of mephedrone users reported a daily use and $17.5 \%$ reported "addiction/ dependence" symptoms. ${ }^{50}$ Likewise, Prosser and Nelson stated strong cravings to repeat or increase doses after taking mephedrone. ${ }^{49}$ As a result of a paucity of data, long-term effects of substituted cathinone use including the potential for addiction/dependence remain largely unknown.

\section{Pharmacokinetics}

Mephedrone, methylone, ethylone, MDPV, and naphyrone showed high blood-brain barrier permeability in an in vitro model with mephedrone and MDPV exhibiting particularly high permeability. ${ }^{29}$ Pyrrolidine ring and tertiary amino groups 
improve liphophilicity. ${ }^{68}$ In rats, the plasma concentrations versus time curve after intravenous administration of $10 \mathrm{mg} /$ $\mathrm{kg}$ methylone were described by a two-compartment model with distribution and terminal phases of $\alpha=1.95$ hour 1 and $\beta=0.72$ hour 1 . The steady state apparent volume of distribution and total plasma clearance was $2.39 \mathrm{~L} / \mathrm{kg}$ and $0.53 \mathrm{~L} /$ hour, respectively. Maximal concentration values were achieved within 0.5 hour and 1 hour. Absolute bioavailability was about $80 \%$ after oral administration. ${ }^{34}$ In a sympathomimetic toxicity case report, naphyrone half-live was estimated at around 34 hours and was consistent with the known long-lasting effect of naphyrone. ${ }^{69}$ Insufflation provides a quicker onset of action and shorter duration of effect compared to ingestion, with the total experience lasting a few hours. The central action of buphedrone, which is stronger than methylcathinone, persists after nasal application for about 6 hours. ${ }^{70}$

\section{Distribution}

In postmortem cases analyzed for methylone, mephedrone, and MDPV, analysis of several tissue samples (liver, kidney, and spleen) show that methylone does not sequester in a particular tissue type after death. ${ }^{71}$ Following lethal intoxication, MDPV was fairly uniformly distributed among tissues at a value of approximately 0.4 to $0.6 \mathrm{mg} / \mathrm{L}$ (blood, brain, muscle, spleen, lung, and kidneys). Levels in different brain regions reflected a higher concentration in parietal, cerebellum, medulla, and occipital regions than in the frontal and lentiform nucleus. ${ }^{10}$

\section{Metabolism}

The designer drug PPP ( $\alpha$-pyrrolidinopropiophenone) is extensively metabolized by rats. The main pathways were hydroxylation of the pyrrolidine ring with subsequent dehydrogenation to the corresponding lactam, hydroxylation of the aromatic ring in position 4' or double dealkylation of the pyrrolidine ring to the corresponding primary amine partly followed by reduction of the keto group to the corresponding secondary alcohol. ${ }^{72,73}$ All other pyrrolidinophenone-derived designer drugs were mainly metabolized at their aromatic substituents, by oxidation of the methyl group (MPPP, MPHP [methyl- $\alpha$-pyrrolidinohexanophe none]), by O-demethylation of the methoxy moiety (MOPPP), or by demethylation of the methylenedioxy moiety (MDPPP). Hydroxylation of the side chain could be observed for the derivative with long side chain (MPHP). Metabolic phase 2 pathways were methylation, glucuronidation, or sulfation. ${ }^{74}$ Initial hydroxylation of the $4^{\prime}$-methyl moiety of MPPP and MPHP, O-demethylation of MOPPP, and demethylenation of MDPPP were catalyzed by cytochrome P450 (CYP) 2D6 (major) and CYP2C19; CYP1A2, CYP2B6, and CYP2C9 were addition- ally involved in MPPP and MPHP hydroxylation to a minor extent. ${ }^{74}$ Furthermore, MPPP is a substrate of CYP2D6 and may represent a kinetic drug interaction risk. ${ }^{75}$

\section{Concentrations in biological samples}

Concentrations of substituted cathinone in blood reported after recreational use appear to be below $0.1 \mathrm{mg} / \mathrm{L}$. By contrast, in cases of acute toxicity, blood levels often exceed this value. Meanwhile, blood concentration does not appear to accurately predict outcome regarding fatalities.

In a study that surveyed mephedrone concentrations in impaired driving cases $(\mathrm{n}=32)$, blood concentrations ranged up to $0.74 \mathrm{mg} / \mathrm{L}$ (mean: $0.21 \mathrm{mg} / \mathrm{L}$ ); in cases in which mephedrone was the only drug detected $(n=9)$ concentrations ranged up to $0.66 \mathrm{mg} / \mathrm{L}$ (mean: $0.27 \mathrm{mg} / \mathrm{L}) .{ }^{76}$ In a case of recreational use of naphyrone that produced acute sympathomimetic toxicity, naphyrone concentrations were $0.03 \mathrm{mg} / \mathrm{L}$ and $0.02 \mathrm{mg} / \mathrm{L}$, 40 hours and 60 hours after drug intake, respectively. ${ }^{69}$ In a patient with signs of toxic liver damage and rhabdomyolysis followed by renal insufficiency repeatedly treated by hemodialysis, MPHP was found in serum in a concentration of approximately $0.1 \mathrm{mg} / \mathrm{L} .{ }^{77}$ In a 23 -year old man with a prior psychiatric history arriving via emergency medical service for bizarre behavior, suicidality, and hallucinations, serum and urine were found to contain MDPV at concentrations of $0.186 \mathrm{mg} / \mathrm{L}$ and $0.136 \mathrm{mg} / \mathrm{L}$, respectively, and flephedrone at concentrations of $0.346 \mathrm{mg} / \mathrm{L}$ and $0.257 \mathrm{mg} / \mathrm{L}$, respectively. ${ }^{78}$ The concentrations measured in several fatal cases in which death was attributed directly to cathinone toxicity alone are outlined in Table 7 . In a series of 13 positive hair cases for

Table 7 Blood concentrations measured in several fatal cases

\begin{tabular}{lllll}
\hline $\begin{array}{l}\text { Substituted } \\
\text { cathinone }\end{array}$ & Sex & $\begin{array}{l}\text { Age } \\
\text { (year) }\end{array}$ & $\begin{array}{l}\text { Blood concentration } \\
\text { (mg/L) }\end{array}$ & Reference \\
\hline Butylone & Male & 21 & 20 & 105 \\
MDPV & Female & 35 & 1.2 & 80 \\
MDPV & Male & 39 & 1.0 & 106 \\
Mephedrone & Female & 49 & 0.98 & 107 \\
Mephedrone & Male & 19 & 2.24 & 107 \\
Methedrone & Male & 23 & $8.4^{*}$ & 101 \\
Methedrone & Male & 19 & $9.6 *$ & 101 \\
Methylone & Male & 19 & 0.74 & 71 \\
Methylone & Male & 38 & 0.11 & 71 \\
Methylone & Female & 35 & 1.1 & 71 \\
Methylone & Male & 23 & $0.84 ; 1$ & 108 \\
Methylone & Female & 19 & 3.3 & 108 \\
Methylone & Male & 23 & 0.58 & 108 \\
Methylone & Male & 19 & 0.7 & 109 \\
Methylone & Male & 16 & 0.227 & 57 \\
\hline Note: & & & &
\end{tabular}

Note: ${ }^{*} \mathrm{mg} / \mathrm{kg}$.

Abbreviation: MDPV, methylenedioxypyrovalerone. 
mephedrone, concentrations ranged from $0.2 \mathrm{ng} / \mathrm{mg}$ to 313.2 ng/mg. ${ }^{79}$ Postmortem MDPV was detected in hair at $11.7 \mu \mathrm{g} /$ $\mathrm{g}^{10}$ or $22 \mathrm{ng} / 10 \mathrm{~mm}^{80}$

\section{Clinical management of acute and chronic adverse effects and addiction}

There are limited reliable data to guide clinicians in managing patients with toxicity due to substituted cathinones. Management of users with acute toxic effects is mainly extrapolated from experience with longer established stimulants or hallucinogenic drugs.

\section{Diagnostic tests}

Routine laboratory tests in the work-up of a potentially synthetic cathinone toxic patient include: 1) a basic metabolic panel with blood glucose levels, serum electrolyte concentrations (sodium and potassium), and serum osmolarity if hyponatremia is present, liver and kidney function tests (transaminases, alanine transaminase/aspartate transaminase [ALT/AST], gamma-glutamyl transpeptidase [GGT], alkaline phosphatase, total and unbound bilirubin, creatinine, and urea); 2) a complete blood cell count with coagulation studies (activated partial thromboplastin time, prothrombin time, platelet count, and p-dimer); 3) cardiac markers (troponin and creatine kinase $\mathrm{MB}$ ); and 4) total creatinine kinase to exclude potential rhabdomyolysis and myoglobin in urine if there are signs of rhabdomyolysis. ${ }^{81}$ The typically available urine toxicology screens will not detect the vast majority of synthetic cathinones (see section on Current and developing analytical methods for detection), but could be useful to detect other possibly ingested substances. More specific and sensitive chromatographic methods associated with MS could successfully identify substituted cathinone. Electrocardiograms might also be useful especially if the patient is profoundly tachycardic and electroencephalogram might be indicated if seizure is suspected or observed.

\section{Clinical exam}

In addition to the aforementioned laboratory tests, detailed physical and neurological exams are imperative. Common physical signs of use and intoxication include: tachycardia, hypertension, hyperthermia, diaphoresis, mydriasis, hyperreflexia, myoclonus, seizures, tremors, irritability, anxiety, and paranoia. A proper history taking of the patient is also required, but is sometimes difficult to obtain as patients frequently present highly intoxicated and are uncooperative due to various psychiatric symptoms and agitation. Moreover, the level of agitation frequently requires physical restraints and safety protocol/monitoring implementation.

The combination of various bath-salt compounds present in available products, and other illegal substances or alcohol involved, can lead to significant differences in presentation, with signs of catecholamine and serotonergic toxicities ranging from mild neurological and neurovegetative symptoms to more severe symptoms. Concurrent use of serotonergic drugs may also increase the risk of serotonergic syndrome leading to multiple system failures, most notably cardiac, renal, and neurologic.

\section{Treatment}

Appropriate supportive care and addressing any complications is the primary treatment for the acutely intoxicated patient. No specific antidote exists for synthetic cathinone exposure and no curative treatment is approved by health authorities. Hydration with intravenous fluids should be initiated along with measures to actively cool patients if they are hyperthermic. Hypertonic saline or water restriction should be prescribed if the patient becomes hyponatremic. ${ }^{82}$ Agitation and seizures associated with acute toxidrome should be managed with benzodiazepines as a first step. Antipsychotics (intramuscular haloperidol or oral risperidone) could be an effective therapeutic alternative to treat excitement, violent behavior, or psychosis. ${ }^{83}$ However, haloperidol may contribute to hyperthermia and dysrhythmias. ${ }^{84}$ As a general rule, the use of dopamine blocking (antipsychotic) agents that may potentially exacerbate thermoregulatory disturbances should be carefully managed in cathinoneintoxicated patients. A case of treating cathinone dependence and comorbid depression using bupropion was reported in 2012, but research regarding the potential effectiveness of bupropion in these cases is needed. ${ }^{85}$ Electroconvulsive therapy improved persistent psychotic symptoms observed in a patient who discontinues repeated use of MDPV. ${ }^{86}$ In 15 mephedrone users admitted to a London emergency department, $20 \%$ required treatment with benzodiazepines predominantly for management of agitation. ${ }^{87}$ The clinical experience of two regional poison centers in the US reported the use of benzodiazepines $(n=125)$, antipsychotics $(n=47)$, and propofol $(\mathrm{n}=10)$ to treat severe medical outcomes (one death, eight major, and 130 moderate) in 236 synthetic cathinone users. ${ }^{88}$

After recovery, substituted cathinone abusers should be referred for psychiatric consultation. Spiller et al reported the primary disposition of these patients: $49 \%$ were treated and 
released from the emergency department, 21\% were admitted to critical care, $12 \%$ were admitted to psychiatry, and $12 \%$ were lost to follow up. ${ }^{88}$ Unfortunately, to date, no pharmacological therapy has been approved by the US Food and Drug Administration (FDA) to treat psychostimulant addiction. ${ }^{89}$

\section{Legal status}

Cathinone derivatives have different legal status around the world. Cathinone and methcathinone are listed in Schedule I of the United Nations 1971 Convention on Psychotropic Substances. Amfepramone and pyrovalerone are in Schedule IV of that Convention, but a large number of synthetic cathinone derivatives are not under international control. Recently, the World Health Organization (WHO) expert committee did not consider that the abuse liability of methylbenzodioxolylbutanamine (MBDB) would constitute a significant risk to public health that could necessitate its placement under international control.

In the US, pyrovalerone is a Schedule V substance. ${ }^{90}$ In 2011, the Department of Justice issued a final order in the Federal Register, temporarily placing the three synthetic stimulants, mephedrone, MDPV, and methylone, under Schedule I of the Controlled Substances Act. On July 2012, MDPV and mephedrone were permanently banned. Recently, the Synthetic Cathinones Control Act of 2013 planned to provide for the specified placement of methylone and 14 other substituted cathinones on Schedule I of the Controlled Substances Act. ${ }^{91}$

The European Council adopted a decision on submitting mephedrone to control measures across the European Union in $2010 .{ }^{92} \mathrm{~A}$ few other cathinone derivatives, such as methylone, butylone, MDPV, and flephedrone, are controlled in some Member States of the EU under drug control or equivalent legislation. In addition, generic control in the UK under the UK's Misuse of Drugs Act in April 2010 and France in August 2012 covers a wide group of cathinone derivatives.

\section{Availability and usage demographics}

The misuse of synthetic cathinones is not new. Methcathinone, originally used as an antidepressant in the former Soviet Union in the 1930 s, went on to be used recreationally during the 1970s and 1980s. The emergence of the popularity of methcathinone in countries such as the US rang some alarm bells in the 1990s. Although mephedrone was first synthesized in 1929, it really became an attractive cocaine and MDMA replacement during the early 2000s. ${ }^{93}$ The first seizure of substituted cathinone (capsules containing mephedrone) was reported in 2007 in Finland. In 2008 mephedrone was also detected in the UK and other scandinavian countries. By the end of 2010 it had been detected in 31 European and neighboring countries, suggesting widespread availability throughout Europe. ${ }^{92}$ In the UK, mephedrone first appeared widespread among clubbers before enjoying popularity among young adults and teenagers. ${ }^{67}$

Nowadays, substituted cathinones are largely available online and in retail stores for recreational public or private use. Cathinones are mostly encountered as a white, off-white, or slightly yellow-colored fine powder, as racemic mixtures and hydrochloride salts, and mainly sold in small packages of $200 \mathrm{mg}$ to $500 \mathrm{mg}$, sometimes in the form of capsule or tablet. The synthesis of these cathinone derivatives is relatively easy and Internet sites are also used for the purchase of the starting materials, the most common being the appropriate propiophenone or alphabromopropiophenone. ${ }^{5}$

Prior to being banned under the UK's Misuse of Drugs Act in April 2010, mephedrone, which is reported as easy to obtain, was widely used among school and college/ university students: 205 of 1,006 surveyed individuals had used mephedrone on at least one occasion. ${ }^{50}$ Interviewed mephedrone users tended to obtain mephedrone mainly through friends/acquaintances, dealers, and less commonly from Internet-based head shops to avoid "drug user" identities. Following the ban, they reported a greater reliance on dealers, a change in packaging, and a rise in prices. ${ }^{94}$ By contrast, despite media attention focusing on synthetic cathinone use as a growing epidemic, the prevalence of use among a population of 2,349 students in a large university in the Southeastern US was extremely rare (1.07\%). ${ }^{95}$

Aside from this problematic misuse, it is important to remember that several cathinones, such as diethylpropion, bupropion, or pyrovalerone have been used medically as antidepressants and that bupropion is still currently used as a smoking cessation aid.

\section{Conclusion}

Substituted cathinones, initially considered as "legal highs", have been used in the recreational drug markets not only for their own hedonic and euphoric effects but as a replacement for other tightly regulated stimulants, such as cocaine or amphetamine. Experimental and clinical reports clearly demonstrate the acute cardiovascular and central nervous system toxicity due to the intensive abuse and binge intake patterns of these substances, in combination with the high risk of death related to the powerful stimulation of the catecholaminergic system. Furthermore, the dopaminergic stimulation of the 
reward system could explain the development of dependence after frequent consumption of cathinone derivatives. In addition, these "highs" are often taken in conjunction with other recreational drugs or alcohol, which increases the potential for health-related complications. Despite their now illegal status in many countries, substituted cathinones continue to be prevalent drugs of abuse with MDPV and mephedrone being the chief substances detected in blood and urine from patients hospitalized for cathinone derivative overdose. Accordingly, clinicians should be aware of this developing trend as an explanation for patients presenting with unexplained delirious toxidromes or secondary psychoses. Routine toxicology screens may not detect the presence of these compounds and more specific methods may be required for identification and quantification in biological samples. This analytical step is crucial in clinics and forensics to clarify the extent to which peripheral and central monoamine systems might be affected. Indeed, concentrations of substituted cathinones are measured in a rather narrow window between use and fatality cases which may further differ from one compound to another. All information collected will be useful for professional continuing education of the clinician pertaining to new trends of substituted cathinone abuse. Meanwhile, substituted cathinones represent only part of synthetic derivatives available on the online market. An ever-increasing diversity of new products not under control are manufactured to supply an ever-increasing and diversified demand for psychoactive substances. In conclusion, it seems that: 1) emergency departments will continue to encounter patients suffering from complications caused by synthetic stimulants; 2) clinicians should remain vigilant of the risk of increasing morbidity and mortality associated with these products; and 3) as key health care practitioners, physicians and pharmacists must continue to feed databases of case reports and help promote awareness of this problem in their communities.

\section{Disclosure}

The authors report no conflicts of interest in this work.

\section{References}

1. Brandt SD, Freeman S, Sumnall HR, Measham F, Cole J. Analysis of NRG 'legal highs' in the UK: identification and formation of novel cathinones. Drug Test Anal. 2011;3(9):569-575.

2. Ojanperä LA, Heikman PK, Rasanen IJ. Urine analysis of 3,4-methylenedioxypyrovalerone in opioid-dependant patients by gas chromatography-mass spectrometry. Ther Drug Monitoring. 2011;33:257-263.

3. Macher AM, Penders TM. False-positive phencyclidine immunoassay results caused by 3,4-methylenedioxypyrovalerone (MDPV). Drug Test Anal. 2013;5(2):130-132.
4. Swortwood MJ, Hearn WL, Decaprio AP. Cross-reactivity of designer drugs, including cathinone derivatives, in commercial enzyme-linked immunosorbent assays. Drug Test Anal. 2013.

5. McDermott SD, Power JD, Kavanagh P, O'Brien J. The analysis of substituted cathinones. Part 2: an investigation into the phenylacetone based isomers of 4-methylmethcathinone and N-ethylcathinone. Forensic Sci Int. 2011;212(1-3):13-21.

6. Kavanagh P, O'Brien J, Fox J, et al. The analysis of substituted cathinones. Part 3. Synthesis and characterisation of 2,3-methylenedioxy substituted cathinones. Forensic Sci Int. 2012;216(1-3):19-28.

7. Zuba D, Adamowicz P, Byrska B. Detection of buphedrone in biological and non-biological material - two case reports. Forensic Sci Int. 2013;227(1-3):15-20.

8. Archer RP. Fluoromethcathinone, a new substance of abuse. Forensic Sci Int. 2009;185(1-3):10-20.

9. Torrance H, Cooper G. The detection of mephedrone (4-methylmethcathinone) in 4 fatalities in Scotland. Forensic Sci Int. 2010;202(1-3):e62-e63.

10. Wyman JF, Lavins ES, Engelhart D, et al. Postmortem tissue distribution of MDPV following lethal intoxication by "bath salts". J Anal Toxicol. 2013;37(3):182-185.

11. O'Byrne PM, Kavanagh PV, McNamara SM, Stokes SM. Screening of stimulants including designer drugs in urine using a liquid chromatography tandem mass spectrometry system. J Anal Toxicol. 2013;37(2): 64-73.

12. Bell C, George C, Kicman AT, Traynor A. Development of a rapid LC-MS/MS method for direct urinalysis of designer drugs. Drug Test Anal. 2011;3(7-8):496-504.

13. Strano-Rossi S, Cadwallader AB, de la Torre X, Botrè F. Toxicological determination and in vitro metabolism of the designer drug methylenedioxypyrovalerone (MDPV) by gas chromatography/mass spectrometry and liquid chromatography/quadrupole time-of-flight mass spectrometry. Rapid Commun Mass Spectrom. 2010;24(18): 2706-2714.

14. Marinetti LJ, Antonides HM. Analysis of synthetic cathinones commonly found in bath salts in human performance and postmortem toxicology: method development, drug distribution and interpretation of results. $J$ Anal Toxicol. 2013;37(3):135-146.

15. Ambach L, Hernández Redondo A, König S, Weinmann W. Rapid and simple LC-MS/MS screening of 64 novel psychoactive substances using dried blood spots. Drug Test Anal. Epub 2013 Jul 19.

16. Lesiak AD, Musah RA, Cody RB, Domin MA, Dane AJ, Shepard JR. Direct analysis in real time mass spectrometry (DART-MS) of "bath salt" cathinone drug mixtures. Analyst. 2013;138(12):3424-3432.

17. Vircks KE, Mulligan CC. Rapid screening of synthetic cathinones as trace residues and in authentic seizures using a portable mass spectrometer equipped with desorption electrospray ionization. Rapid Commun Mass Spectrom. 2012;26(23):2665-2672.

18. Wang X, Vernikovskaya DI, Abdelrahman DR, Hankins GD, Ahmed MS, Nanovskaya TN. Simultaneous quantitative determination of bupropion and its three major metabolites in human umbilical cord plasma and placental tissue using high-performance liquid chromatography-tandem mass spectrometry. J Pharm Biomed Anal. 2012;70:320-329.

19. Sørensen LK. Determination of cathinones and related ephedrines in forensic whole-blood samples by liquid-chromatography-electrospray tandem mass spectrometry. J Chromatogr B Analyt Technol Biomed Life Sci. 2011;879(11-12):727-736.

20. Zuba D. Identification of cathinones and other active components of "legal highs" by mass spectrometric methods. Trends Anal Chem. 2012;32:15.

21. Fornal E. Identification of substituted cathinones: 3,4-Methylenedioxy derivatives by high performance liquid chromatography-quadrupole time of flight mass spectrometry. J Pharm Biomed Anal. 2013;81-82: 13-19.

22. Sundström M, Pelander A, Angerer V, Hutter M, Kneisel S, Ojanperä I. A high-sensitivity ultra-high performance liquid chromatography/highresolution time-of-flight mass spectrometry (UHPLC-HR-TOFMS) method for screening synthetic cannabinoids and other drugs of abuse in urine. Anal Bioanal Chem. 2013;405(26):8463-8474. 
23. Gottardo R, Sorio D, Musile G, et al. Screening for synthetic cannabinoids in hair by using LC-QTOF MS: A new and powerful approach to study the penetration of these new psychoactive substances in the population. Med Sci Law. 2014;54(1):22-27.

24. Ammann D, McLaren JM, Gerostamoulos D, Beyer J. Detection and quantification of new designer drugs in human blood: Part 2 - Designer cathinones. J Anal Toxicol. 2012;36(6):381-389.

25. Mayer M, Benko A, Huszár A, et al. Simultaneous determination of 4-substituted cathinones (4-MMC, 4-MEC and 4-FMC) in human urine by HPLC-DAD. J Chromatogr Sci. 2013;51(9):861-866.

26. Meltzer PC, Butler D, Deschamps JR, Madras BK. 1-(4-Methylphenyl)2-pyrrolidin-1-yl-pentan-1-one (Pyrovalerone) analogues: a promising class of monoamine uptake inhibitors. J Med Chem. 2006;49(4): 1420-1432.

27. Baumann MH, Partilla JS, Lehner KR. Psychoactive "bath salts": not so soothing. Eur J Pharmacol. 2013;698(1-3):1-5.

28. Eshleman AJ, Wolfrum KM, Hatfield MG, Johnson RA, Murphy KV, Janowsky A. Substituted methcathinones differ in transporter and receptor interactions. Biochem Pharmacol. 2013;85(12):1803-1815.

29. Simmler LD, Buser TA, Donzelli M, et al. Pharmacological characterization of designer cathinones in vitro. Br J Pharmacol. 2013;168(2): $458-470$.

30. Sogawa C, Sogawa N, Ohyama K, et al. Methylone and monoamine transporters: correlation with toxicity. Curr Neuropharmacol. 2011; 9(1):58-62.

31. Cameron K, Kolanos R, Vekariya R, Verkariya R, De Felice L, Glennon RA. Mephedrone and methylenedioxypyrovalerone (MDPV), major constituents of "bath salts," produce opposite effects at the human dopamine transporter. Psychopharmacology (Berl). 2013;227(3): 493-499.

32. Marusich JA, Grant KR, Blough BE, Wiley JL. Effects of synthetic cathinones contained in "bath salts" on motor behavior and a functional observational battery in mice. Neurotoxicology. 2012;33(5): 1305-1313.

33. den Hollander B, Rozov S, Linden AM, Uusi-Oukari M, Ojanperä I, Korpi ER. Long-term cognitive and neurochemical effects of "bath salt" designer drugs methylone and mephedrone. Pharmacol Biochem Behav. 2013;103(3):501-509.

34. López-Arnau R, Martínez-Clemente J, Carbó Ml, Pubill D, Escubedo E, Camarasa J. An integrated pharmacokinetic and pharmacodynamic study of a new drug of abuse, methylone, a synthetic cathinone sold as "bath salts". Prog Neuropsychopharmacol Biol Psychiatry. 2013;45:64-72.

35. Shortall SE, Macerola AE, Swaby RT, et al. Behavioural and neurochemical comparison of chronic intermittent cathinone, mephedrone and MDMA administration to the rat. Eur Neuropsychopharmacol. 2013;23(9):1085-1095.

36. Gatch MB, Taylor CM, Forster MJ. Locomotor stimulant and discriminative stimulus effects of 'bath salt' cathinones. Behav Pharmacol. 2013;24(5-6):437-447.

37. Fantegrossi WE, Gannon BM, Zimmerman SM, Rice KC. In vivo effects of abused 'bath salt' constituent 3,4-methylenedioxypyrovalerone (MDPV) in mice: drug discrimination, thermoregulation, and locomotor activity. Neuropsychopharmacology. 2013;38(4):563-573.

38. Aarde SM, Huang PK, Creehan KM, Dickerson TJ, Taffe MA. The novel recreational drug 3,4-methylenedioxypyrovalerone (MDPV) is a potent psychomotor stimulant: self-administration and locomotor activity in rats. Neuropharmacology. 2013;71:130-140.

39. Zelger JL, Schorno HX, Carlini EA. Behavioural effects of cathinone, an amine obtained from Catha edulis Forsk.: comparisons with amphetamine, norpseudoephedrine, apomorphine and nomifensine. Bull Narc. 1980;32(3):67-81.

40. Glennon RA, Yousif M, Naiman N, Kalix P. Methcathinone: a new and potent amphetamine-like agent. Pharmacol Biochem Behav. 1987;26(3):547-551.

41. Yanagita T. Intravenous self-administration of (-)-cathinone and 2-amino1-(2,5-dimethoxy-4-methyl)phenylpropane in rhesus monkeys. Drug Alcohol Depend. 1986;17(2-3):135-141.
42. Goudie AJ. Importing khat, legal but dangerous. Lancet. 1987; 2(8571):1340-1341.

43. Schechter MD, Rosecrans JA, Glennon RA. Comparison of behavioral effects of cathinone, amphetamine and apomorphine. Pharmacol Biochem Behav. 1984;20(2):181-184.

44. Watterson LR, Kufahl PR, Nemirovsky NE, et al. Potent rewarding and reinforcing effects of the synthetic cathinone 3,4-methylenedioxypyrovalerone (MDPV). Addict Biol. 2012.

45. Forrester MB. Synthetic cathinone exposures reported to Texas poison centers. Am J Drug Alcohol Abuse. 2012;38(6):609-615.

46. EROWID [homepage on the Internet]. Available from: http://www.erowid. org. Accessed on: January 5, 2014.

47. Drugs-Forum [homepage on the Internet]. SIN Foundation; 2012. Available from: http://www.drugs-forum.com. Accessed on January 5, 2014.

48. Sumnall H, Wooding O. Mephedrone: an update on current knowledge. Liverpool: Centre for public health, Liverpool John Moores University; 2010.

49. Prosser JM, Nelson LS. The toxicology of bath salts: a review of synthetic cathinones. J Med Toxicol. 2012;8(1):33-42.

50. Dargan PI, Albert S, Wood DM. Mephedrone use and associated adverse effects in school and college/university students before the UK legislation change. QJM. 2010;103(11):875-879.

51. Wood DM, Dargan PI. Mephedrone (4-methylmethcathinone): what is new in our understanding of its use and toxicity. Prog Neuropsychopharmacol Biol Psychiatry. 2012;39(2):227-233.

52. Sammler EM, Foley PL, Lauder GD, Wilson SJ, Goudie AR, O'Riordan JI. A harmless high? Lancet. 2010;376(9742):742.

53. Boulanger-Gobeil C, St-Onge M, Laliberté M, Auger PL. Seizures and hyponatremia related to ethcathinone and methylone poisoning. $\mathrm{J} \mathrm{Med}$ Toxicol. 2012;8(1):59-61.

54. Nicholson PJ, Quinn MJ, Dodd JD. Headshop heartache: acute mephedrone 'meow' myocarditis. Heart. 2010;96(24):2051-2052.

55. James D, Adams RD, Spears R, et al; National Poisons Information Service. Clinical characteristics of mephedrone toxicity reported to the UK National Poisons Information Service. Emerg Med J. 2011;28(8): 686-689.

56. Levine M, Levitan R, Skolnik A. Compartment syndrome after "bath salts" use: a case series. Ann Emerg Med. 2013;61(4):480-483.

57. Kovács K, Tóth AR, Kereszty EM. [A new designer drug: methylone related death]. Orv Hetil. 2012;153(7):271-276. Hungarian.

58. Schifano F, Corkery J, Ghodse AH. Suspected and confirmed fatalities associated with mephedrone (4-methylmethcathinone, "meow meow") in the United Kingdom. J Clin Psychopharmacol. 2012;32(5):710-714.

59. Ross EA, Reisfield GM, Watson MC, Chronister CW, Goldberger BA. Psychoactive "bath salts" intoxication with methylenedioxypyrovalerone. Am J Med. 2012;125(9):854-858.

60. Stepens A, Stagg CJ, Platkajis A, Boudrias MH, Johansen-Berg H, Donaghy $\mathrm{M}$. White matter abnormalities in methcathinone abusers with an extrapyramidal syndrome. Brain. 2010;133(Pt 12):3676-3684.

61. Sikk K, Haldre S, Aquilonius SM, et al. Manganese-induced parkinsonism in methcathinone abusers: bio-markers of exposure and follow-up. Eur J Neurol. 2013;20(6):915-920.

62. Penders TM, Lang MC, Pagano JJ, Gooding ZS. Electroconvulsive therapy improves persistent psychosis after repeated use of methylenedioxypyrovalerone ("bath salts"). J ECT. 2013;29(4):e59-e60.

63. Rothman RB, Baumann MH, Dersch CM, et al. Amphetamine-type central nervous system stimulants release norepinephrine more potently than they release dopamine and serotonin. Synapse. 2001;39(1):32-41.

64. Wee S, Anderson KG, Baumann MH, Rothman RB, Blough BE, Woolverton WL. Relationship between the serotonergic activity and reinforcing effects of a series of amphetamine analogs. J Pharmacol Exp Ther. 2005;313(2):848-854.

65. Baumann MH, Clark RD, Woolverton WL, Wee S, Blough BE, Rothman RB. In vivo effects of amphetamine analogs reveal evidence for serotonergic inhibition of mesolimbic dopamine transmission in the rat. $J$ Pharmacol Exp Ther. 2011;337(1):218-225. 
66. Brunt TM, Poortman A, Niesink RJ, van den Brink W. Instability of the ecstasy market and a new kid on the block: mephedrone. J Psychopharmacol. 2011;25(11):1543-1547.

67. Johnson LA, Johnson RL, Portier RB. Current "legal highs". J Emerg Med. 2013;44(6):1108-1115.

68. Coppola M, Mondola R. 3,4-methylenedioxypyrovalerone (MDPV): chemistry, pharmacology and toxicology of a new designer drug of abuse marketed online. Toxicol Lett. 2012;208(1):12-15.

69. Derungs A, Schietzel S, Meyer MR, Maurer HH, Krähenbühl S, Liechti ME. Sympathomimetic toxicity in a case of analytically confirmed recreational use of naphyrone (naphthylpyrovalerone). Clin Toxicol (Phila). 2011;49(7):691-693.

70. Biliński P, Hołownia P, Kapka-Skrzypczak L, Wojtyła A. Designer Drug (DD) abuse in Poland; a review of the psychoactive and toxic properties of substances found from seizures of illegal drug products and the legal consequences thereof. Part II--piperazines/piperidines, phenylethylamines, tryptamines and miscellaneous 'others'. Ann Agric Environ Med. 2012;19(4):871-882.

71. Cawrse BM, Levine B, Jufer RA, et al. Distribution of methylone in four postmortem cases. J Anal Toxicol. 2012;36(6):434-439.

72. Springer D, Fritschi G, Maurer HH. Metabolism of the new designer drug alpha-pyrrolidinopropiophenone (PPP) and the toxicological detection of PPP and 4'-methyl-alpha-pyrrolidinopropiophenone (MPPP) studied in rat urine using gas chromatography-mass spectrometry. J Chromatogr B Analyt Technol Biomed Life Sci. 2003;796(2):253-266.

73. Staack RF, Maurer HH. Metabolism of designer drugs of abuse. Curr Drug Metab. 2005;6(3):259-274

74. Maurer HH, KraemerT, Springer D, Staack RF. Chemistry, pharmacology, toxicology, and hepatic metabolism of designer drugs of the amphetamine (ecstasy), piperazine, and pyrrolidinophenone types: a synopsis. Ther Drug Monit. 2004;26(2):127-131.

75. Pritzker D, Kanungo A, Kilicarslan T, Tyndale RF, Sellers EM. Designer drugs that are potent inhibitors of CYP2D6. J Clin Psychopharmacol. 2002;22(3):330-332.

76. Cosbey SH, Peters KL, Quinn A, Bentley A. Mephedrone (methylmethcathinone) in toxicology casework: a Northern Ireland perspective. J Anal Toxicol. 2013;37(2):74-82.

77. Sauer C, Hoffmann K, Schimmel U, Peters FT. Acute poisoning involving the pyrrolidinophenone-type designer drug 4'-methyl-alphapyrrolidinohexanophenone (MPHP). Forensic Sci Int. 2011;208(1-3): e20-e25.

78. Thornton SL, Gerona RR, Tomaszewski CA. Psychosis from a bath salt product containing flephedrone and MDPV with serum, urine, and product quantification. J Med Toxicol. 2012;8(3):310-313.

79. Martin M, Muller JF, Turner K, Duez M, Cirimele V. Evidence of mephedrone chronic abuse through hair analysis using GC/MS. Forensic Sci Int. 2012;218(1-3):44-48.

80. Namera A, Urabe S, Saito T, et al. A fatal case of 3,4-methylenedioxypyrovalerone poisoning: coexistence of $\alpha$-pyrrolidinobutiophenone and $\alpha$ - pyrrolidinovalerophenone on blood and/or hair. Forensic Toxicol. 2013;31(2): 338-343.

81. Mas-Morey P, Visser MH, Winkelmolen L, Touw DJ. Clinical toxicology and management of intoxications with synthetic cathinones ("bath salts"). J Pharm Pract. 2013;26(4):353-357.

82. Prosser JM, Nelson LS. The toxicology of bath salts: a review of synthetic cathinones. J Med Toxicol. 2012;8(1):33-42.

83. Kasick DP, McKnight CA, Klisovic E. "Bath salt" ingestion leading to severe intoxication delirium: two cases and a brief review of the emergence of mephedrone use. Am J Drug Alcohol Abuse. 2012;38(2): $176-180$.

84. Blom MT, Bardai A, van Munster BC, et al. Differential changes in QTc duration during in-hospital haloperidol use. PLoS One. 2011;6(9):e23728.

85. Lev-Ran S. A case of treating cathinone dependence and comorbid depression using bupropion. J Psychoactive Drugs. 2012;44(5): 434-436.
86. Penders TM, Lang MC, Pagano JJ, Gooding ZS. Electroconvulsive therapy improves persistent psychosis after repeated use of methylenedioxypyrovalerone ("bath salts"). J ECT. 2013;29(4): e59-e60.

87. Wood DM, Greene SL, Dargan PI. Clinical pattern of toxicity associated with the novel synthetic cathinone mephedrone. Emerg Med J. 2011;28(4):280-282.

88. Spiller HA, Ryan ML, Weston RG, Jansen J. Clinical experience with and analytical confirmation of "bath salts" and "legal highs" (synthetic cathinones) in the United States. Clin Toxicol (Phila). 2011;49(6): 499-505.

89. Taylor SB, Lewis CR, Olive MF. The neurocircuitry of illicit psychostimulant addiction: acute and chronic effects in humans. Subst Abuse Rehabil. 2013;4:29-43.

90. Johnson LA, Johnson RL, Portier RB. Current "legal highs". J Emerg Med. 2013;44(6):1108-1115.

91. German CL, Fleckenstein AE, Hanson GR. Bath salts and synthetic cathinones: An emerging designer drug phenomenon. Life Sci. 2013. In press.

92. European Monitoring Centre for Drugs and Drug Addiction [webpage on the Internet]. EMCDDA: Drug-related topics - Drug profiles. Lisbon: EMCDDA; 2013. Available from: http://www.emcdda.europa. eu/publications/drug-profiles. Accessed January 5, 2014.

93. Brunt TM, Poortman A, Niesink RJ, van den Brink W. Instability of the ecstasy market and a new kid on the block: mephedrone. J Psychopharmacol. 2011;25(11):1543-1547.

94. McElrath K, O'Neill C. Experiences with mephedrone pre- and post-legislative controls: perceptions of safety and sources of supply. Int J Drug Policy. 2011;22(2):120-127.

95. Stogner JM, Miller BL. Investigating the 'bath salt' panic: the rarity of synthetic cathinone use among students in the United States. Drug Alcohol Rev. 2013;32(5):545-549.

96. Zaitsu K, Katagi M, Kamata HT, Miki A, Tsuchihashi H. Discrimination and identification of regioisomeric $\beta$-keto analogues of 3,4-methylenedioxyamphetamines by gas chromatography-mass spectrometry. Forensic Toxicol. 2008;26:45-51.

97. Westphal F, Junge T. Ring positional differentiation of isomeric $\mathrm{N}$-alkylated fluorocathinones by gas chromatography/tandem mass spectrometry. Forensic Sci Int. 2012;223(1-3):97-105.

98. Abiedalla YF, Abdel-Hay K, DeRuiter J, Clark CR. Synthesis and GC-MS analysis of a series of homologs and regioisomers of 3,4-methylenedioxypyrovalerone (MDPV). Forensic Sci Int. 2012; 223(1-3):189-197.

99. Springer D, Fritschi G, Maurer HH. Metabolism and toxicological detection of the new designer drug 4'-methoxy-alpha-pyrrolidinopropiophenone studied in rat urine using gas chromatography-mass spectrometry. $J$ Chromatogr B Analyt Technol Biomed Life Sci. 2003;793(2):331-342.

100. Gil D, Adamowicz P, Skulska A, Tokarczyk B, Stanaszek R. Analysis of 4-MEC in biological and non-biological material - three case reports. Forensic Sci Int. 2013;228(1-3):e11-e15.

101. Wikström M, Thelander G, Nyström I, Kronstrand R. Two fatal intoxications with the new designer drug methedrone (4-methoxymethcathinone). J Anal Toxicol. 2010;34(9):594-598.

102. Westphal F, Junge T, Rösner P, Fritschi G, Klein B, Girreser U. Mass spectral and NMR spectral data of two new designer drugs with an alphaaminophenone structure: $4^{\prime}$-methyl-alpha-pyrrolidinohexanophenone and 4'-methyl-alpha-pyrrolidinobutyrophenone. Forensic Sci Int. 2007;169(1):32-42.

103. Brandt SD, Wootton RC, De Paoli G, Freeman S. The naphyrone story: The alpha or beta-naphthyl isomer? Drug Test Anal. 2010; 2(10):496-502.

104. Westphal F, Junge T, Girreser U, Greibl W, Doering C. Mass, NMR and IR spectroscopic characterization of pentedrone and pentylone and identification of their isocathinone by-products. Forensic Sci Int. 2012;217(1-3):157-167.

105. Rojek S, Kłys M, Strona M, Maciów M, Kula K. "Legal highs" toxicity in the clinical and medico-legal aspect as exemplified by suicide with bk-MBDB administration. Forensic Sci Int. 2012; 222(1-3):e1-e6. 
106. Kesha K, Boggs CL, Ripple MG, et al. Methylenedioxypyrovalerone ("bath salts"), related death: case report and review of the literature. $J$ Forensic Sci. 2013;58(6):1654-1659.

107. Maskell PD, De Paoli G, Seneviratne C, Pounder DJ. Mephedrone (4-methylmethcathinone)-related deaths. J Anal Toxicol. 2011; 35(3):188-191.
108. Pearson JM, Hargraves TL, Hair LS, et al. Three fatal intoxications due to methylone. J Anal Toxicol. 2012;36(6):444- 451.

109. Carbone PN, Carbone DL, Carstairs SD, Luzi SA. Sudden cardiac death associated with methylone use. Am J Forensic Med Pathol. 2013;34(1):26-28.

\section{Publish your work in this journal}

Substance Abuse and Rehabilitation is an international, peer-reviewed, open access journal publishing original research, case reports, editorials, reviews and commentaries on all areas of addiction and substance abuse and options for treatment and rehabilitation. The manuscript management system is completely online and includes a very quick and fair peer-review system. Visit http://www.dovepress.com/testimonials.php to read real quotes from published authors. 